\title{
Changes in abundance, diversity and metabolic footprint of soil nematode community along an elevation gradient under temperate vegetation cover in Banihal-Pass of Pir-Panjal mountain range
}

\section{Shahid Afzal}

Aligarh Muslim University

Humira Nesar

Aligarh Muslim University

Zarrin Imran

Aligarh Muslim University

Wasim Ahmad ( $\square$ ahmadwasim57@gmail.com )

Aligarh Muslim University

\section{Research Article}

Keywords: Soil nematodes, elevation gradient, abundance, diversity, metabolic footprint, belowground ecosystem

Posted Date: April 9th, 2021

DOI: https://doi.org/10.21203/rs.3.rs-394973/v1

License: (c) (i) This work is licensed under a Creative Commons Attribution 4.0 International License. Read Full License

Version of Record: A version of this preprint was published at Scientific Reports on August 10th, 2021. See the published version at https://doi.org/10.1038/s41598-021-95651-x. 
1 Changes in abundance, diversity and metabolic footprint of soil nematode community along an 2 elevation gradient under temperate vegetation cover in Banihal-Pass of Pir-Panjal mountain range.

3 Shahid Afzal ${ }^{1}$, Humira Nesar ${ }^{2}$, Zarrin Imran $^{3}$ and Wasim Ahmad $^{4 *}$

$4 \quad$ Nematode Biodiversity Research Lab, Department of Zoology, Aligarh Muslim University, Aligarh 5202002 India

6 *Corresponding author email address: ahmadwasim57@gmail.com

7

8

9

10

11

12

13

14

15

16

17

18

19

20

21

22

23

24 


\section{Abstract}

26 Despite enormous diversity, abundance and their role in ecosystem processes, little is known about how 27 community structures of soil-inhabiting nematodes differ across elevation gradient. For this, soil 45 nematode communities were investigated along an elevation gradient of 1000 to $2500 \mathrm{~m}$ asl across a temperate vegetation in Banihal-Pass of Pir-Panjal mountain range. We aimed to determine how the elevation gradient affect the nematode community structure, diversity and contribution to belowground carbon assimilation in the form of metabolic footprint. Our results showed that total nematode abundance and the abundance of different trophic groups (fungivores, herbivores and omnivores) declined with the increase of elevation. Shannon index, generic richness and evenness index indicated that nematode communities were more diverse at lower elevations and declined significantly with increase in elevation. Nematode community showed a pattern of decline in overall metabolic footprint with the increase of elevation. Nematode abundances and diversity proved to be more sensitive to elevation induced changes as more abundant and diverse nematode assemblage are supported at lower elevations. Overall it appears nematode abundance, diversity and contribution to belowground carbon cycling is stronger at lower elevations and gradually keep declining towards higher elevations under temperate vegetation cover in Banihal-pass of Pir-Panjal mountain range.

Keywords: Soil nematodes, elevation gradient, abundance, diversity, metabolic footprint, belowground ecosystem

(1)
4 


\section{Introduction}

Soils harbour some of the most diverse microbial community on earth, provide shelter to $25 \%$ worldwide described species and thus considered as a crucial biodiversity reservoir ${ }^{1-6}$. Soil organism's distribution patterns play critical roles in determining the above and belowground primary production and its composition ${ }^{7,8}$. Elevation and its related factors significantly affect the soil abiotic characteristics and the density/biomass patterns of nematode communities, thus alter the microbial functions of soil ecosystem $9-12$

All chemical and physical changes in the soil are rapidly reflected through changes in richness and composition of nematode species ${ }^{13}$. In addition to diversity and functional indices which are useful descriptive tools for assessment of food web and ecosystem condition, various metabolic footprint indices ${ }^{14}$ have been developed to estimate contribution of nematodes to various ecosystem services and functions. Among the landscape properties, altitude rather than vegetation cover is found to have vital effect on nematode community ${ }^{15}$, because altitudinal climatic conditions strongly constrain the availability and turnover of basal resources and can be viewed as nature's own field experiments ${ }^{16}$. Various elevation patterns of diversity have been studied across a wide range of taxonomic groups in aboveground organisms, including trees, mammals, birds, insects and amphibians ${ }^{17}$. However, elevational diversity patterns of belowground organisms, especially those of soil invertebrates which often represent decomposer subsystems, have remained understudied ${ }^{18,4}$.

In the present study, we tried to unravel the distribution and contribution of soil dwelling nematodes to belowground soil food web from 1000 to $2500 \mathrm{~m}$ asl elevation gradient along a pristine temperate forest vegetation cover at Banihal-Pass of Pir-Panjal mountain range which lies in the Western Himalayan region. We assessed total and trophic abundance, biomass, alpha diversity, and metabolic footprint pattern of soil nematodes along the elevation gradient. Since that abiotic factors shape species distributions, fostering fewer species and abundance at high elevations due to harsh climatic conditions compared to 
low elevations. Keeping this in consideration, we hypothesized: (1) a decline in nematode abundance and diversity with increasing elevation and (2) metabolic footprint of nematodes will be suitable indicators of elevation change.

\section{Results}

\subsection{Physicochemical properties of soil along elevation gradient}

Among the abiotic factors (Table 1), soil moisture ( $\mathrm{r}=0.87, p=0.0001$; Fig. 1A), soil organic matter $(\mathrm{r}=0.92, p=0.0001$; Fig. 1B $)$ and proportion of clay $(\mathrm{r}=0.92, p=0.0001$; Fig. 1C) showed significant positive correlation with elevation. While as soil $\mathrm{pH}(\mathrm{r}=-0.87, p=0.0001$; Fig. 1D) significantly declined with increasing elevation.

\subsection{Changes in abundance and biomass of nematode community along elevation gradient}

The total nematode abundance, biomass and diversity were correlated and tested with simple linear regression with elevation (Table 1). From 45 soil samples 30955 nematodes were assigned to 49 different genera (Table 2) in five different trophic groups (bacterivore-12, fungivore-12, omnivore-4, predatory- 8 and herbivore-13). Total nematode abundance (Fig. 2A) as well as abundance of fungivores, omnivores and herbivores (Fig. 2C-E) are negatively correlated with the increase of elevation, whereas the abundance of bacterivores and predators (Fig. 2B \& 2F) did not show any definite pattern. Similarly, the total nematode biomass (Fig. 3A) and biomass of the three trophic groups decreased with elevation (Fig. 3C-E). However, the biomass of both bacterivore and predatory nematodes (Fig. 3B \& 3F) did not show any significant decline with elevation.

\subsection{Diversity indices and metabolic footprint along elevation gradient}

All measured alpha diversity indices reflected a significant negative (Table1) correlation with the increase of elevation. The values of $\mathrm{H}(r=-0.49, d f=43), \mathrm{GR}(r=-0.32, d f=43)$ and $\mathrm{J}(r=-0.42, d f=43)$ negatively correlated with increasing elevation (Fig. 4A-C). The composite metabolic footprint, 
enrichment footprint and structure footprint all decreased with increasing elevation (Fig. 5A-C) indicating the amount of carbon entering the soil food-web from total nematode assemblages.

\subsection{Relationship of soil nematode assemblages with soil physiochemical properties:}

Total nematode abundance was negatively correlated with soil moisture (Fig. 6A) and proportion of clay (Fig. 6D) and positively correlated with pH (Fig 6G). No significant correlation was observed between soil moisture and nematode generic richness (Fig. 6B). However, generic negatively correlated with proportion of clay (Fig. 6E) and positively correlated with pH (Fig.6H). Soil moisture (Fig. 6C) and proportion of clay (Fig. 6F) showed negative influence on diversity $\left(\mathrm{H}^{\prime}\right)$, While as $\mathrm{pH}$ showed positive influence on diversity (Fig.6I).

\section{Discussion}

Elevation is a complicated, indirect gradient along which several environmental variables shift, resulting in a fundamental diversity gradient trend in animal and plant biogeography The temperate vegetation in higher altitudes of Banihal-Pass of Pir-Panjal mountain range experiences extremely harsh climatic conditions with almost half of the precipitation received in the form of snow, because soil remains deep frozen in winter months and experiences significant temperature fluctuations.

In line with our first hypothesis here we observed that total soil nematode abundance and diversity exhibit a significant decline with elevational gradient which is consistent with the results of some earlier studies on nematodes ${ }^{19,20}$ and with other soil fauna including springtails and mites ${ }^{21}$, and other microarthropods ${ }^{22,23}$. In contrast to this, various patterns are found to occur in nematode community along the elevation, at mid-elevation maximum diversity and species richness have been documented ${ }^{24,25}$, in alpine grasslands abundance and diversity increased with elevation ${ }^{26}$. However similar studies on nematodes along gradient did not find any definite pattern ${ }^{27,28}$. As mentioned earlier mountains in PirPanjal range tend to have greater climatic adversities that alter soil conditions, and it is possible that due 
these altered soil conditions explains the survival of sparse and coexistence of fewer nematode species in the higher elevations. Several environmental gradients are held responsible for shaping soil nematode communities .Among the environmental conditions that shift strongly with elevation is temperature, which gradually decreased with elevation (Fig. S1) and proved detrimental for nematode community like other soil organisms. Nematodes are found to be very sensitive to temperature changes with optimal of $20-25^{\circ} \mathrm{C}$ for the survival and propagation, any change in temperature from optimum value leads to significant inhibition in nematode population ${ }^{29,30,31}$. In our study, temperature was below optimum value possibly affecting soil nematode abundance and diversity as conditions were much harsher at higher elevations. Increased soil organic matter and moisture along the elevation gradient (Fig.1) had a negative impact on nematode abundance and diversity, although they are considered as positive drivers of their community $^{32,25,33}$. The reason for this may be the presence of more proportion of clay in soil at higher altitude which reduced the porosity of soil and litter decomposition rate, enhancing water retention that leads to damp soil formation and anaerobic conditions under coniferous vegetation canopy which is rich in $\operatorname{lignin}^{34}$. The reason for the decrease in soil $\mathrm{pH}$ with elevation may be due to the litter accumulation that negatively effects the nematode community, as found in other soil biota ${ }^{35}$.

Variation in nematode abundance belonging to different trophic groups were also observed. Abundance of herbivores, fungivores and omnivores significantly declined with altitude which is in line with Veen et al. ${ }^{36}$. A potential explanation for these findings is that herbivore nematodes are favoured in soils colonized by diverse assemblages of plants with well-developed fine root systems. At higher altitudes vegetation is sparse under forest canopy, possibly depriving food for herbivores which is in accordance with another studies that reported a reduction in the abundance of plant-feeders with altitude 37,12 . For herbivore nematodes, bottom-up effects from plant communities are thought to be more important than top-down pressure from predators ${ }^{38}$. Elevation has no effect on bacterial feeding nematodes in our study, which may be due to basal characteristics bacterial feeders in food web that are mostly dominated by basal fauna. 
143 However another studies ${ }^{26,29}$ reported a definite pattern of increase in bacterivore nematode from lower to 144 higher elevations. The non-significant decline of predatory nematodes could be due to their key position 145 in the soil food web, where they can switch on to different prey based on availability.

146 Similar results were reported by Kergunteuil et al. ${ }^{26}$.

147 The metabolic footprint provides information on magnitude of carbon and energy flow in soil food webs $^{14}$. The nematode metabolic footprint consists of composite metabolic footprint, enrichment footprint and structure footprint which are the representatives of whole nematode community ${ }^{14}$. In our study, we found that the carbon assimilation in soil food web from autotrophic organisms decreased with elevation as found in composite metabolic footprint, enrichment footprint and structure footprint. The enrichment footprint is considered to be an indicator of resource entry into the soil food web ${ }^{39}$. The decline of enrichment footprint with elevation showed less entry of resources in the soil food web at high elevation because of slower decomposition rates influenced by low temperature and winter permafrost. Structure footprint reflects metabolic activity of higher trophic level nematodes, which have regulatory function in the food web $\mathrm{w}^{40,41}$. The decrease in structure footprint with elevation may be related to decrease of resource entry in the food web at higher elevation, indicating a possible bottom-up control of the soil food web. Overall, this decrease in carbon assimilation of whole nematode community could be attributed to retention of more carbon in tree biomass than in soil of these temperate forests at higher elevation, although productivity is high ${ }^{42}$. However, decline in the efficiency of carbon to enter the soil faunal food web through nematodes with increasing altitude may be due to decrease in the availability of amplifiable prey for nematodes. Thus for the mitigation of elevated atmospheric carbon, high altitude forest soils cannot be relied. Additional expansion of lower altitude forests in these regions need to be considered for mitigating and stabilising the elevated atmospheric carbon in soil food webs. Accordingly our second hypothesis that nematode metabolic footprint are the suitable indicators of elevation change suggests whether carbon is partitioned in the soil food web or not. 
167

168

169

170

171

172

173

174

175

176

177

178

179

180

181

182

183

184

185

186

187

188

189

\section{Conclusion}

Our findings from this study indicated that a more abundant and diverse nematode assemblage are supported at lower elevations and keep diminishing along elevation gradient under temperate vegetation cover in Banihal-Pass of Pir-Panjal mountain range. Temperature and local soil microhabitat are the main elevation induced environmental factors which shape the pattern of nematodes. We also observed that the role played by nematodes in carbon cycling decreases with elevation as the carbon footprint of nematodes showed significant decline. However, as elevation gradients are complex in mountain environments, further studies focused on vegetation type, temporal dynamics and biotic interactions of nematodes are needed to validate, whether this pattern is general.

\section{Methods}

\subsection{Study site}

The study site was situated in Banihal-Pass $\left(33.4370^{\circ} \mathrm{N}, 75.1939^{\circ} \mathrm{E}\right)$ of Pir-Panjal mountain range. The region owing to its topography falls in typical temperate zone with maximum elevation of $2832 \mathrm{~m}$. The area experiences a mean annual temperature and precipitation of $15.1^{\circ} \mathrm{C}$ and $1363 \mathrm{~mm}$ respectively. However, change in temperature with elevation was calculated by lapse rate of $0.6^{\circ} \mathrm{C} / 100 \mathrm{~m}^{25}$ (Dong et al. 2017) using an annual base temperature of $15.1^{\circ} \mathrm{C}$ of the study site (Fig. S1). At higher altitudes significant amount of precipitation is received in the form of snowfall. The climate varies with altitude (IMD 2014). The soils of the region are organic rich brown forest soils and podozolic soils. The vegetation cover at altitudes between 1000 and $2000 \mathrm{~m}$ asl is of temperate deciduous type mostly dominated by Pinus roxburghii, Robinia pseudoacacia, Populus spp., Ulmus villosa, Aesculus indica, Juglans regia, Salix spp. The zone between 2000 and $2500 \mathrm{~m}$ asl is of temperate coniferous vegetation having predominance of Albies pindrew, Pinus welichiana and Cedrus deodara. Above $2500 \mathrm{~m}$ asl, the vegetation cover is mostly alpine tundra and alpine pastures. 


\subsection{Soil sampling}

Sampling was conducted in the month of April 2018. A total of 45 soil samples were collected from 15 elevations along a mountain separated from each by $100 \mathrm{~m}$ of elevation. At each elevation, three separate quadrats of $5 \mathrm{~m}^{2}$ were selected, spaced approximately $50 \mathrm{~m}$ apart in a horizontal line. From each quadrat five sub-samples, four from corners and one from centre at a depth $0-15 \mathrm{~cm}$ were combined to form a composite sample of $500 \mathrm{~g}$. These samples were transported to lab within two days.

\subsection{Soil analysis}

Physicochemical analysis of soil: About $350 \mathrm{~g}$ of the soil out of the initial bulk was used for measuring soil properties (soil moisture, soil organic matter, $\mathrm{pH}$, and soil texture). Soil moisture was measured gravimetrically by drying at $40^{\circ} \mathrm{C}$ for seven days. SOM was estimated following loss on ignition $\operatorname{method}^{43}$. Soil $\mathrm{pH}$ was measured by forming a suspension of $20 \mathrm{~g}$ of soil in $40 \mathrm{ml}$ of deionised water using $\mathrm{pH}$ meter (ECPHTUTOR). Soil texture was calculated as the relative proportion of sand, silt, and clay expressed as percentage.

\subsection{Nematode extraction and identification}

From $100 \mathrm{~g}$ of fresh soil sample, nematodes were extracted via decanting and sieving following the Cobb's method ${ }^{44}$. Each soil sample was put into a $1 \mathrm{~L}$ beaker and mixed with tap water. The water suspension was stirred and decanted into another $1 \mathrm{~L}$ beaker through $2 \mathrm{~mm}$ mesh sieve to remove stones and large debris. The water suspension was mixed further and then decanted through $53 \mu \mathrm{m}$ mesh sieve. The material left on the sieve was collected in $250 \mathrm{ml}$ beaker and further extraction was carried out by Baerman's funnel method. Nematodes were removed for 2 days, stored at $4{ }^{\circ} \mathrm{C}$, fixed in TAF and counted using inverted microscope (Olympus SZX10). Additionally, 200 individuals per sample were identified to generic level using compound microscope (Olympus BX41), with the aid of various texts ${ }^{45,46,47,48,49}$. The genera identified were also assigned to different functional guilds ${ }^{50,40}$. 


\subsection{Community analysis}

Nematode abundance and trophic abundance was adjusted as total number of individuals in $100 \mathrm{~g}$ of dry soil. Alpha diversity of nematodes were calculated by Shannon index $\left(H=-\sum_{i=1}^{n} P_{i} \ln P_{i}\right)$, generic richness, Chao1 $=S+F_{1}\left(F_{1}-1\right) /\left(2\left(F_{2}+1\right)\right)$ (where $\mathrm{S}$ is number of genera; F1and $\mathrm{F} 2$ indicate genera represented by one and two individuals of a genus in a sample respectively) and evenness index ( $J=$ $H / \ln S$ ); indices were analysed with PAST $3.26^{51}$. The metabolic footprints which estimates magnitude of ecosystem services and functions provided by nematodes to the soil food web were calculated using the equations:

$W=\left(D^{2} \times L\right) /\left(1.6 \times 10^{6}\right)^{52}$

$F=\Sigma\left(N_{t}\left(0.1\left(W_{t} / m_{t}\right)+0.273\left(W_{t} 0.75\right)\right)^{14}\right.$

Where $W$ is the nematode biomass $(\mu \mathrm{g}), D$ and $L$ are maximum body diameter $(\mu \mathrm{m})$ and body length $(\mu \mathrm{m})$ respectively, $N_{t}$ is the number of nematodes in genus $t, W_{t}$ is the estimated body weight of genus $t$, and $m_{t}$ is the c-p group of the genus $t$. Metabolic footprints were calculated using the NINJA online $\operatorname{program}^{53}$.

\subsection{Statistical analysis}

Spearman correlation and simple linear regression was used to study the effect of elevation on abiotic factors, soil nematode community as well as relationship of soil abiotic factors with soil nematode communities. All statistical analysis and graphs were prepared with the help of software GraphPad Prism8.0.2 $2^{54} . P$ was considered significant below 0.05 . Analysis of four abiotic factors of 45 soil samples was correlated with elevation and tested with simple linear regression. 


\section{References}

235 1. Bardgett, R. The biology of soil: a community and ecosystem approach. Oxford University Press Inc, $236 \quad$ New York (2005).

237 2. Fierer, N. \& Jackson, R. B. The diversity and biogeography of soil bacterial communities. Proc Nat Acad Sci 103, 626-631 (2006). https://doi.org/10.1073/pnas.0507535103

3. Fitter, A. H., Gilligan, C. A., Hollingworth, K., Kleczkowski, A., Twyman, R. M. \& Pitchford, J. W. Biodiversity and ecosystem function in soil. Func Ecol. 19, 369-377 (2005).

4. Decaëns, T. Macroecological patterns in soil communities. Glob Ecol Biogeogr 19, 287-302 (2010).

5. Bardgett, R. D. \& Van Der Putten, W. H. Belowground biodiversity and ecosystem functioning. Nature 515, 505-511 (2014).

6. Bahram, M., Hildebrand. F., Forslund, S. K., Anderson, J. L., Soudzilovskaia, N. A., Bodegom, P. M. \& Huerta-Cepas, J. Structure and function of the global topsoil microbiome. Nature 560, 233-237 (2018).

8. Fisher, F. M., Parker, L. W., Anderson, J. P. \& Whitford, W. G. Nitrogen mineralization in a desert soil: interacting effects of soil moisture and nitrogen fertilizer. Soil Sci Soc America J. 51, 1033-1041 (1987).

9. Yeates, G. W. \& Bongers, T. Nematode diversity in agroecosystems. In: Invertebrate Biodiversity as Bioindicators of Sustainable Landscapes. (Elsevier Science) 113-135 (1999).

10. Ruess, L. Nematode soil faunal analysis of decomposition pathways in different ecosystems. Nematology 5, 179-181 (2003). 
254 11. Nielsen, U. N., Ayres, E., Wall, D. H., Li, G., Bardgett, R. D., Wu, T. \& Garey, J. R. Global-scale 255 patterns of assemblage structure of soil nematodes in relation to climate and ecosystem properties. 256 Glob Ecol and Biogeogr 23, 968-978 (2014).

257 12. Bhusal, D. R., Tsiafouli, M. A. \& Sgardelis, S. P. Temperature-based bioclimatic parameters can 258 predict nematode metabolic footprints. Oecologia 179, 187-199(2015).

259 13. Bloemers, G. F., Hodda, M., Lambshead, P. J. D., Lawton, J. H. \& Wanless, F. R. The effects of forest 260 disturbance on diversity of tropical soil nematodes. Oecologia 111, 575-582 (1997).

261 14. Ferris, H. Form and function: metabolic footprints of nematodes in the soil food web. Eur J Soil Biol $26246,97-104(2010)$.

15. Tsiafouli, M. A., Bhusal, D. R. \& Sgardelis, S. P. Nematode community indices for microhabitat type 264 and large scale landscape properties. Ecol Indicators 73, 472-479 (2017).

16. Körner C. Alpine plants: stressed or adapted. Physiol Plant Ecol 297-312 (1999).

17. Rahbek, C. The role of spatial scale and the perception of large-scale species-richness patterns. Ecol 267 Lett 8, 224-239 (2005).

18. Loranger, G., Bandyopadhyaya, I., Razaka, B. \& Ponge, J. F. Does soil acidity explain altitudinal 269 sequences in collembolan communities? Soil Biol Biochem 33, 381-393 (2001).

19. Liu, J., Yang, Q., Siemann, E., Huang, W. \& Ding, J. Latitudinal and altitudinal patterns of soil 271 nematode communities under tallow tree (Triadica sebifera) in China. Plant Ecol 220, 965-976 272 (2019). 
273 20. Powers, L. E., Ho, M. C., Freckman, D. W. \& Virginia, R. A. Distribution, community structure, and 274 microhabitats of soil invertebrates along an elevational gradient in Taylor Valley, Antarctica. Arct Alp $275 \quad \operatorname{Res} 30,133-141(1998)$.

276 21. Bokhorst, S., Veen, G. C., Sundqvist, M., Jonathan, R., Kardol, P.\& Wardle, D. A. Contrasting 277 responses of springtails and mites to elevation and vegetation type in the sub-Arctic. Pedobiologia 67, $278 \quad 57-64(2018)$

22. Cutz-Pool, L. Q., Palacios-Vargas, J. G., Cano-Santana, Z. \& Castaño-Meneses, G. Diversity patterns of Collembola in an elevational gradient in the NW slope of Iztaccíhuatl volcano, state of Mexico, Mexico. Entomological News 121, 249-261 (2010).

23. Illig, J., Norton, R. A., Scheu, S. \& Maraun, M. Density and community structure of soil- and bark-

24. Devetter, M., Háněl, L., Řeháková, K. \& Doležal, J. Diversity and feeding strategies of soil microfauna along elevation gradients in Himalayan cold deserts. PloS one, 12, e0187646 (2017).

25. Dong, K., Moroenyane, I., Tripathi, B., Kerfahi, D., Takahashi, K., Yamamoto, N. \& Adams, J. Soil nematodes show a mid-elevation diversity maximum and elevational zonation on Mt. Norikura, Japan. Scientific Reports 7: 3028 (2017)

26. Kergunteuil, A., Campos-Herrera, R., Sánchez-Moreno, S., Vittoz, P. \& Rasmann, S. The abundance, diversity, and metabolic footprint of soil nematodes is highest in high elevation alpine grasslands. Front in Ecol and Evol 4, 84 (2016). 
293

294

295

296

297

298

299

300

301

302

303

304

305

306

307

27. Qing, X., Bert, W., Steel, H., Quisado, J. \& de Ley, I. T. Soil and litter nematode diversity of Mount Hamiguitan, the Philippines, with description of Bicirronema hamiguitanense n. sp (Rhabditida: Bicirronematidae). Nematology 17, 325-344 (2015).

28. Tong, F. C. \& Xiao, Y. H. Wang QL Soil nematode community structure on the northern slope of Changbai Mountain, Northeast China. J For Res 21, 93-98 (2010).

29. Bird, A. F. \& Wallace, H. R. The influence of temperature on Meloidogyne hapla and M. javanica. Nematologica 11, 581-589 (1965).

30. Wang, Z. \& Wu, H. Study towards the eco-geographic community of mountain soil nematode in the middle of Hunan. J. Nat. Sci. 15, 72-78 (1992).

31. Landesman, W. J. \& Treonis, A. M. Dighton J Effects of a one-year rainfall manipulation on soil nematode abundances and community composition. Pedobiologia 54, 87-91 (2011).

32. Luo, Y. \& Zhou, X. Soil respiration and the environment. Academic Press, San Diego (2006).

33. Yan, D., Song, X., Yu Z., Peng, D., Ting, X. \& Weng, B. Community structure of soil nematodes under different drought conditions. Geoderma 325, 110-116 (2018).

34. Margesin, R., Minerbi, S. \& Schinner, F. Litter decomposition at two forest sites in the Italian Alps: a field study. Arctic Antarctic and Alpine Research 48, 127-138 (2016).

35. Kappes, H., Lay, R. \& Topp, W. Changes in different trophic levels of litter-dwelling macrofauna associated with giant knotweed invasion. Ecosystems 10, 734-744 (2007).

36. Veen, G. F., De Long, J. R., Kardol, P., Sundqvist, M. K., Snoek, L. B. \& Wardle, D. A. Coordinated responses of soil communities to elevation in three subarctic vegetation types. Oikos 126, 1586-1599 (2017). 
314 37. Gerber, K. Nematodenfauna alpine Böden im Glocknergebiet (Hohe Tauern, Österreich). 315 Veröffentlichungen des Österreichischen Mass-Hochgebirgsprogramms 4, 80-90 (1981).

316 38. Zhang, X., Guan, P., Wang, Y., Li, Q., Zhang, S., Zhang, Z. \& Liang, W. Community composition, 317 diversity and metabolic footprints of soil nematodes in differently-aged temperate forests. Soil Biol 318 Biochem 80, 118-126 (2015).

319 39. Ferris, H., Zheng, L. \& Walker, M. A. Resistance of grape rootstocks to plant-parasitic nematodes. J. $320 \quad$ Nematol 44, 377-386 (2012).

40. Ferris, H., Bongers, T. \& De Goede, R. G. M. A framework for soil food web diagnostics: extension 322 of the nematode faunal analysis concept. Appl Soil Ecol 18, 13-29 (2001).

41. Sánchez-Moreno, S., Nicola, N. L., Ferris, H. \& Zalom, F. G. Effects of agricultural management on nematode-mite assemblages: soil food web indices as predictors of mite community composition. Appl Soil Ecol 41, 107-117 (2009).

42. Dar, T. A., Uddin, M., Khan, M. M. A., Hakeem, K. R. \& Jaleel, H. Jasmonates counter plant stress: a review. Environ Exp Bot 115, 49-57 (2015)

43. Davies, B.E. Loss-on-ignition as an estimate of soil organic matter. Soil Sci Soc America J 38, 150151 (1974).

44. Van, B. J. Methods and techniques for nematology (p. 20). Wageningen, The Netherlands: Wageningen University (2006).

45. Goodey, T. Soil and freshwater nematodes. London, United Kingdom (Methuen and cooperation 333 limited, 1963). 
334 46. Jairajpuri, M. S. \& Ahmad, W. Dorylaimida: free-living, predaceous and plant-parasitic nematodes. 335 (Brill, Boston,1992).

336 47. Ahmad, W. Plant Parasitic Nematodes of India. Litho Offset Printers, Aligarh, Uttar Pradesh (1996).

337 48. Andrássy, I. Free-living nematodes of Hungary (Nematoda errantia), I. In: C. Csuzdi \& S. Mahunka 338 (Eds.), Pedozoologica Hungarica No. 3. Hungarian Natural History Museum. Budapest, Hungary. 3392005.

49. Ahmad, W. \& Jairajpuri, M. S. Mononchida: the predaceous nematodes. Nematology Monographs and Prespectives (Brill, Boston 2010).

50. Bongers, T. \& Bongers, M. Functional diversity of nematodes. Appl Soil Ecol 10, 239-251 (1998).

51. Hammer, O., Harper, D. \& Ryan, P. PAST: Paleontological Statistics Software Package for Education and Data Analysis. Palaeontologia Electronica. 4, 1-9. (2001).

52. Andrassy, I. The determination of volume and weight of nematodes. Acta Zool Acad Sci Hung 2, 1-15 (1956).

53. Sieriebriennikov, B., Ferris, H. \& de Goede, R. G. NINJA: an automated calculation system for nematode-based biological monitoring. Eur J Soil Biol 61, 90-93 (2014).

54. “Sperman's correlation and linear regression was performed using GraphPad Prism version 8.0.2 for Windows, GraphPad Software, La Jolla California USA, www.graphpad.com".

\section{Acknowledgements}

The authors are thankful to the Aligarh Muslim University for providing the required facilities. The first and second author are thankful to the Council of Scientific and Industrial Research and University Grants 
354 Commission, New Delhi for financial support under CSIR-JRF and Maulana Azad National Fellowship 355 (MANF) respectively.

\section{Authors' contributions}

357 SA conducted survey in the month of April 2018; conducted all community and statistical analyses; and 358 led writing of the manuscript. WA helped to develop the study design and also contributed in the editing 359 of manuscript. ALL the authors contributed to writing and editing the manuscript. The authors read and 360 approved the final manuscript.

\section{Competing interests}

362 The authors declare that they do not have any competing interests.

363 Fig. 1: Effect of elevation on soil moisture (A), soil organic matter (B), proportion of clay (C) and $\mathrm{pH}$ 364 (D). Equation for $Y, R^{2}$ (coefficient of determination), $p$ value of linear regression and line of linear 365 regression are shown.

Fig. 2: Relationship between elevation and total abundance of nematodes (A), trophic groups:

Fig. 3: Relationship between elevation and total biomass of nematodes (A), biomass of trophic groups: (coefficient of determination), $p$ (significance) of linear regression and regression line are displayed only for significant relationships. only for significant relationships. 
Fig. 4: Relationship between elevation and total nematode diversity (A), generic richness (B) and evenness (C). Equation for $Y, R^{2}$ (coefficient of determination), $p$ (significance) of linear regression and regression line are displayed only for significant relationships.

Fig. 5: Relationship between elevation and composite metabolic footprint (A), enrichment footprint (B) and structure footprint (C). Equation for $Y, R^{2}$ (correlation coefficient), $p$ (significance) of linear regression and regression line are displayed.

Fig. 6: Relationship of soil moisture, and proportion of clay with total nematode abundance, GR and $\mathrm{H}^{\prime}$ (A-I). Equation for $Y, R^{2}$ (coefficient of determination), $p$ (significance) of linear regression and regression line are displayed only for significant relationships.

Fig. S1: Effect of elevation on Mean Annual Temperature $\left({ }^{\circ} \mathrm{C}\right)$.

\section{Abbreviations}

m asl: meters above sea level; MAT: mean annual temperature; IMD: Indian Meteorological Department;

SOM: Soil organic matter; TAF: Triethanolamine formaldehyde; TNEM: total nematode

\section{Declarations}

\section{Ethics approval and consent to participate}

Not applicable

\section{Consent for publication}

Not applicable

\section{Availability of data and materials}

The datasets generated during and/or analyzed during the current study are available from the corresponding author on reasonable request. 


\section{$400 \quad$ Funding}

$401 \quad$ Not applicable

\section{Authors' information}

403 SA, HN and ZI are members of research team of Prof. Wasim Ahmad who is expertise in the field of 404 nematode systematics and ecology. SA and HN are working as doctoral students in NBR Lab, Department 405 of Zoology, ZI is working as a faculty in the same department. 
Table 1 Slope coefficients, $P$ values and standard errors (SE) for linear regressions showing the relationships between elevation and abiotic factors, nematode abundance, biomass, diversity and metabolic footprint.

\begin{tabular}{|l|l|c|c|c|}
\hline Category & Variables & Slope & $P$ value & SE \\
\hline Abiotic factors & Soil moisture & 0.02847 & $<0.0001$ & 0.0023 \\
\hline & Soil organic matter & 0.008233 & $<0.0001$ & 0.0005 \\
\hline & Clay proportion & 0.01970 & $<0.0001$ & 0.0011 \\
\hline & Soil pH & -0.00174 & $<0.0001$ & 0.0001 \\
\hline Abundance & Total nematodes & -0.5068 & 0.0042 & 0.1676 \\
\hline & Bacterivores & -0.1713 & 0.0530 & 0.0821 \\
\hline & Fungivores & -0.1707 & 0.0231 & 0.0724 \\
\hline & Herbivores & -0.1067 & 0.0099 & 0.0395 \\
\hline & Omnivores & -0.02952 & 0.0052 & 0.0100 \\
\hline & Predators & -0.02851 & 0.1003 & 0.0169 \\
\hline & Total nematodes & -0.00042 & 0.0042 & 0.0001 \\
\hline & Bacterivores & -8.93100 & 0.0530 & 4.8390 \\
\hline & Fungivores & -5.78500 & 0.0231 & 2.4500 \\
\hline & Omnivores & -0.06194 & 0.0099 & 0.0209 \\
\hline & Predators & -0.00011 & 0.0052 & 8.3780 \\
\hline & Shannon index $(H)$ & -0.00046 & 0.0004 & 0.0001 \\
\hline & Generic richness $($ Chao1) & -0.00262 & 0.0216 & 0.0010 \\
\hline & Evenness $(J)$ & -0.00012 & 0.0024 & 3.8860 \\
\hline & Composite & -0.1347 & 0.0013 & 0.0390 \\
\hline Metabolic footprint & Enrichment & -0.02629 & 0.0196 & 0.0108 \\
\hline & Structure & -0.04426 & 0.0260 & 0.0192 \\
\hline & & & & \\
\hline & & & & \\
& & & &
\end{tabular}


Table 2. Mean relative abundance of nematode genera (\%) along elevation gradient. ( $\mathrm{n}=3)$. ${ }^{\text {a }}$ Elevation in metres above sea level ${ }^{b}$ Functional guild is composite of trophic group and cp value:Ba, Bacterivore; Fu, Fungivore; He, Herbivore; Om, Omnivore; Pr, Predator. Trophic groups and cp values are after Yeates et al. (1993) and Bongers and (Bongers 1988), respectively.

\begin{tabular}{|c|c|c|c|c|c|c|c|c|c|c|c|c|c|c|c|c|}
\hline \multirow[b]{2}{*}{ Genus } & \multirow{2}{*}{$\begin{array}{l}\text { Functional } \\
\text { guild }^{\mathrm{b}}\end{array}$} & \multicolumn{15}{|c|}{ Elevation $^{\mathrm{a}}$} \\
\hline & & $\begin{array}{c}1000 \\
\mathrm{~m}\end{array}$ & $\begin{array}{c}1100 \\
\mathrm{~m}\end{array}$ & $\begin{array}{c}1200 \\
\mathrm{~m}\end{array}$ & $\begin{array}{c}1300 \\
\mathrm{~m}\end{array}$ & $\begin{array}{c}1400 \\
\mathrm{~m}\end{array}$ & $\begin{array}{c}1500 \\
\mathrm{~m}\end{array}$ & $\begin{array}{c}1600 \\
\mathrm{~m}\end{array}$ & $\begin{array}{c}1700 \\
\mathrm{~m}\end{array}$ & $\begin{array}{c}1800 \\
\mathrm{~m}\end{array}$ & $\begin{array}{c}1900 \\
\mathrm{~m}\end{array}$ & $\begin{array}{c}2000 \\
\mathrm{~m}\end{array}$ & $\begin{array}{c}2100 \\
\mathrm{~m}\end{array}$ & $\begin{array}{c}2200 \\
\mathrm{~m}\end{array}$ & $\begin{array}{c}2300 \\
\mathrm{~m}\end{array}$ & $\begin{array}{c}2400 \\
\mathrm{~m}\end{array}$ \\
\hline \multicolumn{17}{|l|}{ Bacterivores } \\
\hline Acrobeles & $\mathrm{Ba} 2$ & 0.0 & 0.0 & 2.5 & 0.0 & 5.3 & 0.0 & 0.0 & 6.4 & 0.0 & 20.4 & 0.0 & 0.0 & 26.1 & 1.3 & 0.2 \\
\hline Acrobeloides & $\mathrm{Ba} 2$ & 21.0 & 40.4 & 20.8 & 32.5 & 10.7 & 52.0 & 43.7 & 5.4 & 32.5 & 10.6 & 46.0 & 59.6 & 20.5 & 48.3 & 34.2 \\
\hline Alaimus & $\mathrm{Ba} 4$ & 3.9 & 1.6 & 0.5 & 2.8 & 2.1 & 0.1 & 1.1 & 0.1 & 0.0 & 0.2 & 1.3 & 0.0 & 17.6 & 0.2 & 0.0 \\
\hline Cephalobus & $\mathrm{Ba} 2$ & 3.9 & 2.7 & 2.0 & 2.8 & 5.1 & 0.7 & 1.0 & 2.1 & 2.4 & 1.9 & $\begin{array}{ll}0.4 \\
\end{array}$ & 3.7 & 2.5 & 1.2 & 1.2 \\
\hline Chiloplacus & $\mathrm{Ba} 2$ & 0.0 & 0.0 & 0.0 & 0.0 & 0.0 & 0.4 & 1.5 & 0.0 & 0.0 & 0.0 & 0.0 & 0.0 & 0.0 & 0.0 & 0.0 \\
\hline Diplogaster & Ba1 & 0.0 & 0.0 & 8.7 & 0.0 & 0.0 & 0.0 & 0.0 & 0.0 & 0.0 & 0.4 & 0.0 & 0.0 & 0.0 & 0.0 & 0.0 \\
\hline Eucephalobus & $\mathrm{Ba} 2$ & 0.4 & 0.0 & 0.0 & 0.0 & 0.1 & 0.8 & 0.0 & 0.0 & 0.0 & 0.0 & 0.0 & 0.0 & 0.0 & 2.6 & 4.3 \\
\hline Mesorhabditis & Ba1 & 12.4 & 2.8 & 1.5 & 1.1 & 10.7 & 14.6 & 1.2 & 9.6 & 3.1 & 2.6 & 2.0 & 1.1 & 1.2 & 11.9 & 12.6 \\
\hline Monhystera & $\mathrm{Ba} 2$ & 0.1 & 0.0 & 0.0 & 0.0 & 0.0 & 0.4 & 0.0 & 0.0 & 0.0 & 0.0 & 0.0 & 0.0 & 0.0 & 0.0 & 0.0 \\
\hline Plectus & $\mathrm{Ba} 2$ & 1.7 & 2.7 & 3.9 & 1.8 & 2.8 & 0.4 & 3.0 & 3.9 & 1.9 & 12.7 & 2.0 & 4.5 & 0.7 & 2.9 & 5.7 \\
\hline Prismatolaimus & $\mathrm{Ba} 3$ & 1.6 & 3.2 & 0.2 & 1.1 & 0.0 & 0.0 & 0.0 & 0.0 & 0.0 & 0.0 & 0.2 & 0.0 & 0.4 & 0.0 & 0.0 \\
\hline Wilsonema & $\mathrm{Ba} 2$ & 0.2 & 0.6 & 0.2 & 0.0 & 0.2 & 0.0 & 0.0 & 0.0 & 0.0 & 0.0 & 0.0 & 0.0 & 0.0 & 0.0 & 0.0 \\
\hline \multicolumn{17}{|l|}{ Fungivores } \\
\hline Aglenchus & Fu2 & 0.0 & 0.0 & 0.0 & 0.0 & 0.0 & 0.0 & 0.0 & 0.0 & 0.0 & 10.4 & 0.0 & 0.0 & 0.0 & 1.1 & 2.0 \\
\hline Aphelenchoides & Fu2 & 0.2 & 0.2 & 1.4 & 0.0 & 13.1 & 2.2 & 2.0 & 0.0 & 0.0 & 0.0 & 0.0 & 0.0 & 0.2 & 5.1 & 13.7 \\
\hline Aphelenchus & Fu2 & 4.2 & 14.8 & 15.6 & 10.1 & 0.2 & 10.1 & 17.4 & 7.7 & 15.6 & 4.2 & 10.8 & 8.3 & 4.5 & 7.1 & 3.1 \\
\hline Axonchium & Fu5 & 0.0 & 0.0 & 0.2 & 0.0 & 0.0 & 0.0 & 0.0 & 0.0 & 0.0 & 0.0 & 0.0 & 0.0 & 0.0 & 0.0 & 0.0 \\
\hline Belondira & Fu5 & 0.0 & 0.0 & 5.7 & 0.0 & 0.0 & 0.0 & 0.0 & 0.0 & 0.0 & 0.0 & 0.0 & 0.0 & 0.0 & 0.0 & 0.0 \\
\hline Ditylenchus & Fu2 & 0.0 & 0.0 & 0.0 & 0.0 & 0.0 & 0.2 & 0.7 & 0.0 & 0.0 & 0.0 & 0.0 & 0.0 & 0.0 & 0.0 & 0.0 \\
\hline Doryllium & Fu4 & 1.1 & 0.2 & 8.7 & 14.8 & 0.6 & 2.4 & 8.2 & 12.8 & 2.2 & 2.7 & 3.1 & 3.7 & 7.6 & 3.1 & 0.3 \\
\hline Filenchus & Fu2 & 1.3 & 0.0 & 4.9 & 2.4 & 14.5 & 0.9 & 6.4 & 4.3 & 1.7 & 1.5 & 4.3 & 2.9 & 3.7 & 4.7 & 3.6 \\
\hline Oxydirus & Fu5 & 0.0 & 0.0 & 0.5 & 0.5 & 4.1 & 0.0 & 0.0 & 0.0 & 0.0 & 0.4 & 0.6 & 1.0 & 1.5 & 0.2 & 1.5 \\
\hline Tylencholaimellus & Fu4 & 3.8 & 2.4 & 0.3 & 2.6 & 3.9 & 0.9 & 0.6 & 8.4 & 1.1 & 0.0 & 1.9 & 3.0 & 3.2 & 0.5 & 1.3 \\
\hline Tylencholaimus & Fu4 & 0.0 & 0.0 & 0.2 & 0.0 & 3.1 & 1.6 & 0.3 & 0.9 & 0.7 & 0.0 & 0.0 & 0.0 & 0.0 & 0.0 & 0.0 \\
\hline Tylenchus & Fu2 & 0.0 & 0.2 & 1.4 & 4.6 & 5.9 & 0.0 & 0.9 & 0.5 & 0.5 & 0.0 & 1.3 & 2.2 & 0.3 & 0.5 & 0.0 \\
\hline Diphtherophora & $\mathrm{He} 2$ & 0.0 & 0.0 & 0.8 & 0.0 & 0.2 & 0.0 & 0.4 & 0.0 & 0.0 & 0.0 & 0.0 & 0.0 & 0.0 & 0.0 & 0.0 \\
\hline \multicolumn{17}{|l|}{ Herbivores } \\
\hline Enchodelus & $\mathrm{He} 4$ & 0.7 & 1.1 & 0.0 & 7.7 & 0.4 & 0.0 & 0.0 & 0.0 & 0.0 & 0.0 & 1.1 & 0.0 & 0.0 & 0.0 & 0.0 \\
\hline Helicotylenchus & $\mathrm{He} 3$ & 11.1 & 4.2 & 5.1 & 3.6 & 0.0 & 2.1 & 0.0 & 14.9 & 24.2 & 12.2 & 0.7 & 0.9 & 3.1 & 1.7 & 3.8 \\
\hline Hemicriconemoides & $\mathrm{He} 3$ & 0.0 & 0.0 & 0.0 & 0.5 & 0.0 & 0.0 & 0.0 & 0.0 & 0.2 & 0.0 & 0.0 & 0.0 & 0.0 & 0.0 & 0.0 \\
\hline Hoplolaimus & $\mathrm{He} 3$ & 0.4 & 0.0 & 0.1 & 0.0 & 0.0 & 0.0 & 0.0 & 0.0 & 0.7 & 0.0 & 0.0 & 0.0 & 0.0 & 0.0 & 0.0 \\
\hline Longidorus & $\mathrm{He} 5$ & 0.9 & 0.3 & 0.0 & 0.0 & 0.0 & 0.0 & 0.0 & 0.0 & 0.0 & 0.0 & 0.0 & 0.0 & 0.0 & 0.0 & 0.0 \\
\hline Merlinius & $\mathrm{He} 3$ & 0.0 & 0.0 & 0.0 & 0.2 & 0.0 & 0.0 & 0.0 & 0.0 & 0.3 & 1.2 & 1.2 & 0.0 & 0.0 & 0.0 & 0.0 \\
\hline Oriverutus & $\mathrm{He} 4$ & 0.0 & 0.0 & 0.5 & 0.0 & 0.0 & 0.0 & 0.0 & 0.0 & 0.0 & 0.0 & 0.0 & 0.0 & 0.0 & 0.0 & 0.0 \\
\hline Paralongidorus & $\mathrm{He} 5$ & 0.0 & 0.2 & 0.0 & 0.0 & 0.0 & 0.0 & 0.0 & 0.0 & 0.0 & 0.0 & 0.0 & 0.0 & 0.0 & 0.0 & 0.0 \\
\hline Pratylenchus & $\mathrm{He} 3$ & 20.8 & 0.0 & 1.6 & 1.5 & 0.0 & 0.0 & 0.2 & 15.8 & 4.4 & 3.9 & 0.5 & 1.4 & 0.0 & 0.9 & 0.0 \\
\hline Psilenchus & $\mathrm{He} 2$ & 1.1 & 0.7 & 1.3 & 0.7 & 2.0 & 0.0 & 0.9 & 0.0 & 0.4 & 0.0 & 0.7 & 0.3 & 0.2 & 0.2 & 0.4 \\
\hline Rotylenchus & $\mathrm{He} 3$ & 0.1 & 9.0 & 1.4 & 0.0 & 2.9 & 0.0 & 0.2 & 0.0 & 0.3 & 0.0 & 0.0 & 0.0 & 0.0 & 0.3 & 0.0 \\
\hline Tylenchorhynchus & $\mathrm{He} 3$ & 0.0 & 0.0 & 1.3 & 0.2 & 0.2 & 0.0 & 0.0 & 0.2 & 3.3 & 0.1 & 0.0 & 0.0 & 0.1 & 0.0 & 0.0 \\
\hline \multicolumn{17}{|l|}{ Omnivores } \\
\hline Crassolabium & Om4 & 0.0 & 0.0 & 0.0 & 0.2 & 0.0 & 0.0 & 1.3 & 1.7 & 0.0 & 0.0 & 0.0 & 0.0 & 0.0 & 0.0 & 0.0 \\
\hline Eudorylaimus & Om4 & 2.1 & 4.8 & 1.8 & 1.7 & 7.6 & 0.0 & 3.4 & 0.0 & 0.9 & 2.6 & 4.3 & 0.8 & 1.0 & 2.8 & 3.8 \\
\hline Mesodorylaimus & Om4 & 0.6 & 0.3 & 2.4 & 0.2 & 2.5 & 7.9 & 1.7 & 1.9 & 0.0 & 0.1 & 1.5 & 0.0 & 0.0 & 0.5 & 0.0 \\
\hline Microdorylaimus & Om4 & 0.0 & 0.0 & 0.0 & 0.0 & 1.5 & 0.0 & 0.0 & 0.0 & 0.0 & 0.0 & 0.0 & 0.0 & 0.0 & 0.0 & 0.0 \\
\hline \multicolumn{17}{|l|}{ Predators } \\
\hline Aporcelaimellus & Pr5 & 3.8 & 2.2 & 0.4 & 0.7 & 0.0 & 0.6 & 1.5 & 2.3 & 1.4 & 3.2 & 10.7 & 2.2 & 1.4 & 1.7 & 2.8 \\
\hline Clarkus & Pr4 & 1.4 & 0.0 & 1.4 & 0.7 & 0.2 & 0.2 & 0.0 & 0.9 & 0.0 & 0.4 & 0.4 & 1.3 & 0.8 & 0.3 & 1.5 \\
\hline Discolaimoides & Pr5 & 0.0 & 0.0 & 0.0 & 0.0 & 0.0 & 0.0 & 0.0 & 0.0 & 0.3 & 0.3 & 0.0 & 0.0 & 0.0 & 0.0 & 0.0 \\
\hline Discolaimus & Pr5 & 0.0 & 0.0 & 0.0 & 0.7 & 0.0 & 0.0 & 0.0 & 0.0 & 0.0 & 1.8 & 2.1 & 1.1 & 0.1 & 0.0 & 0.1 \\
\hline Ironus & Pr4 & 0.0 & 0.2 & 0.0 & 0.0 & 0.0 & 0.0 & 0.0 & 0.0 & 0.0 & 0.0 & 0.0 & 0.0 & 0.0 & 0.0 & 0.0 \\
\hline Metaporcelaimus & Pr5 & 0.0 & 0.0 & 0.2 & 0.0 & 0.0 & 0.0 & 0.2 & 0.0 & 0.0 & 0.0 & 0.0 & 0.0 & 0.0 & 0.0 & 0.0 \\
\hline Moshajia & Pr5 & 0.0 & 0.0 & 0.0 & 0.5 & 0.0 & 1.3 & 1.8 & 0.2 & 0.7 & 0.0 & 0.2 & 0.0 & 0.0 & 0.0 & 0.0 \\
\hline Mylonchulus & $\operatorname{Pr} 4$ & 1.1 & 5.2 & 2.7 & 3.8 & 0.3 & 0.0 & 0.4 & 0.0 & 1.1 & 6.2 & 2.8 & 1.9 & 3.1 & 1.0 & 3.8 \\
\hline
\end{tabular}



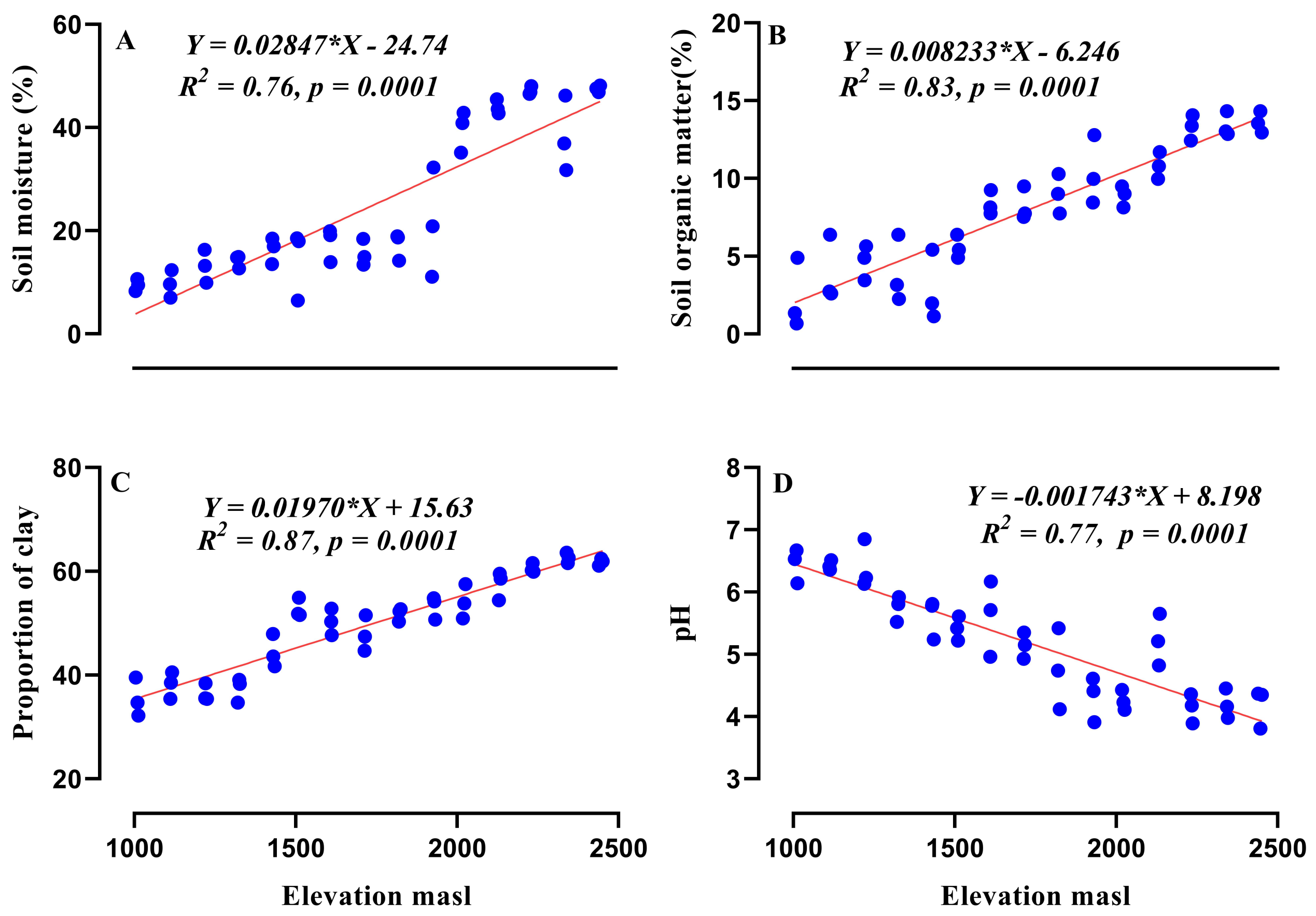

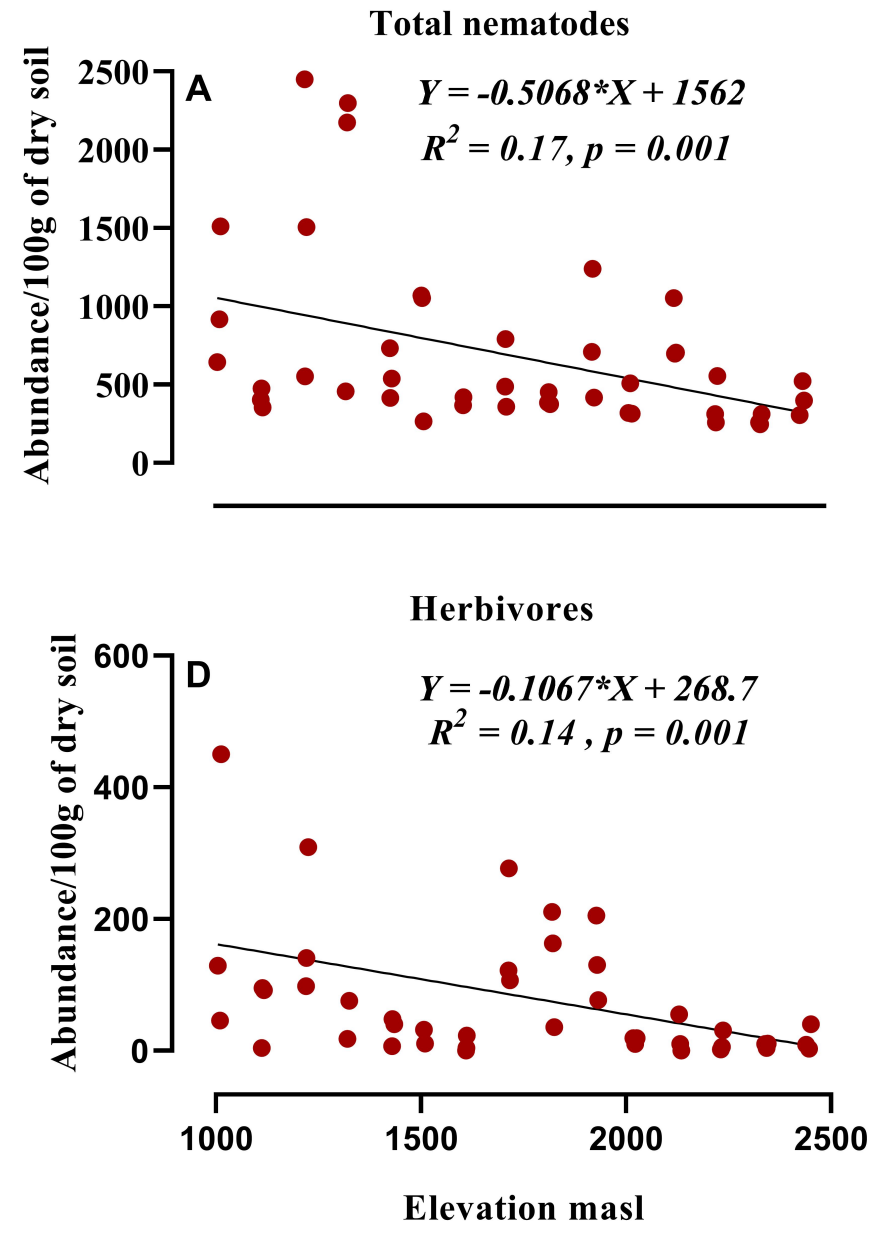
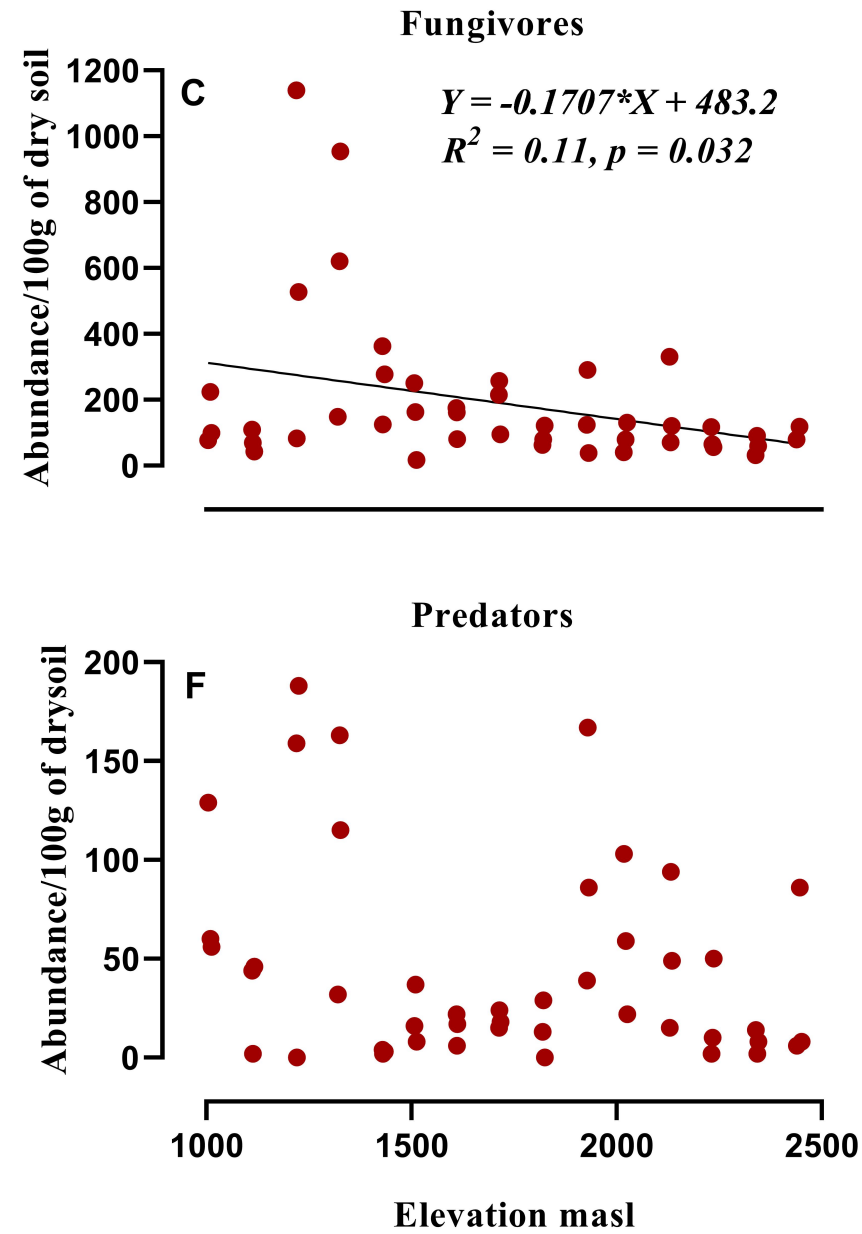
Total nematodes

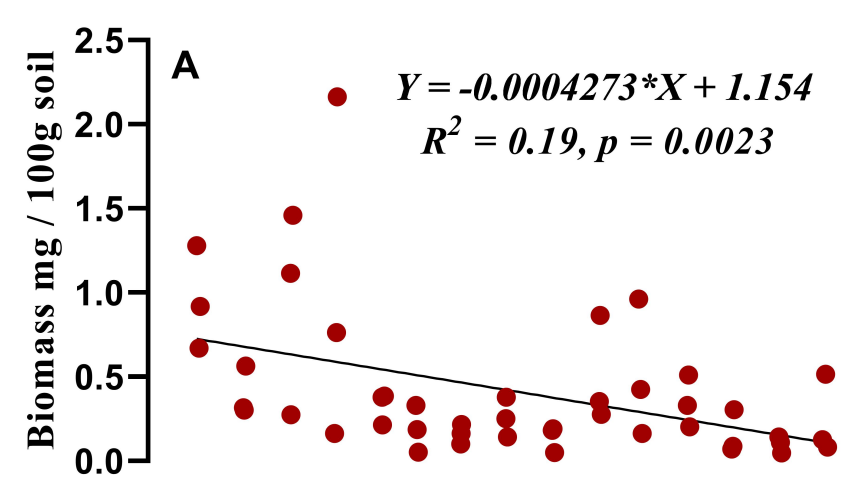

Herbivores
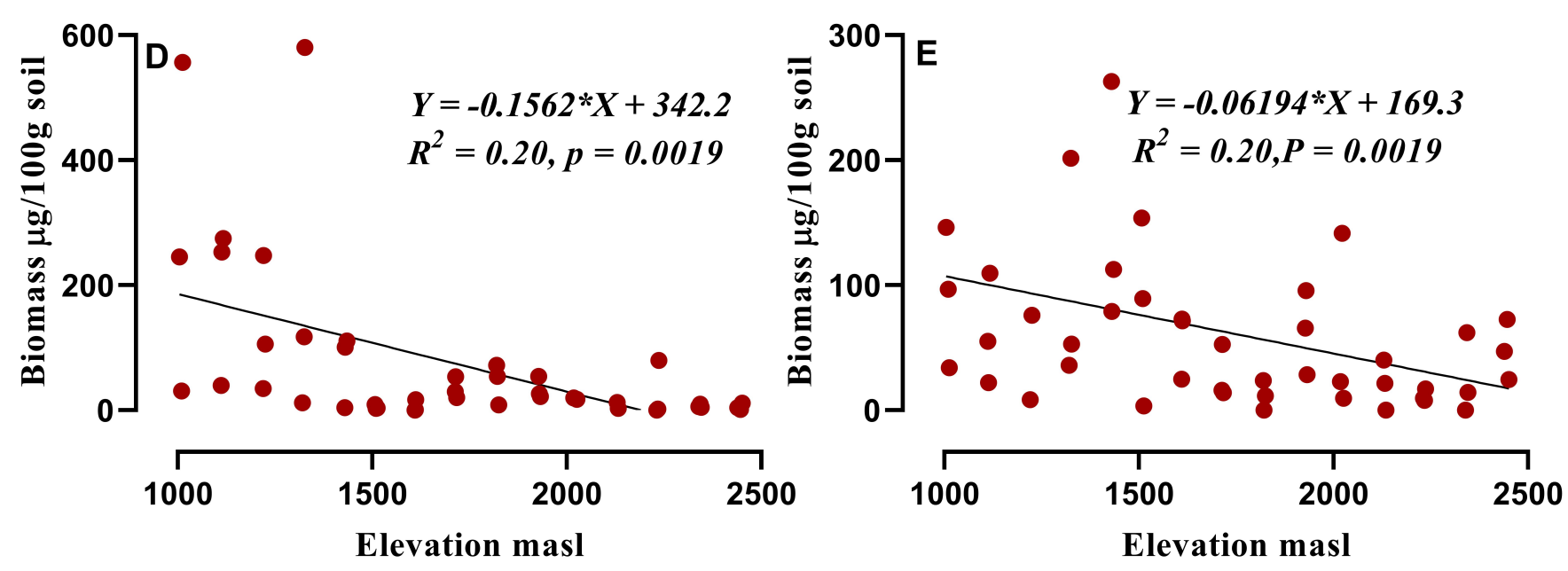

Fungivores

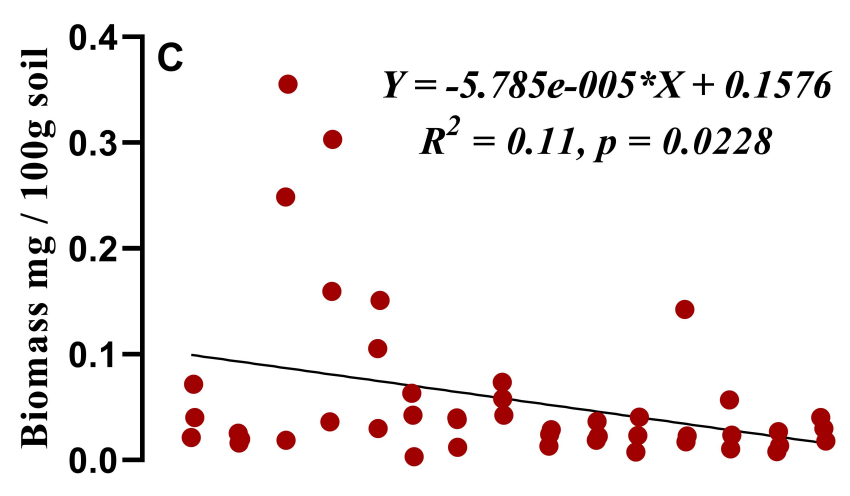

Predator

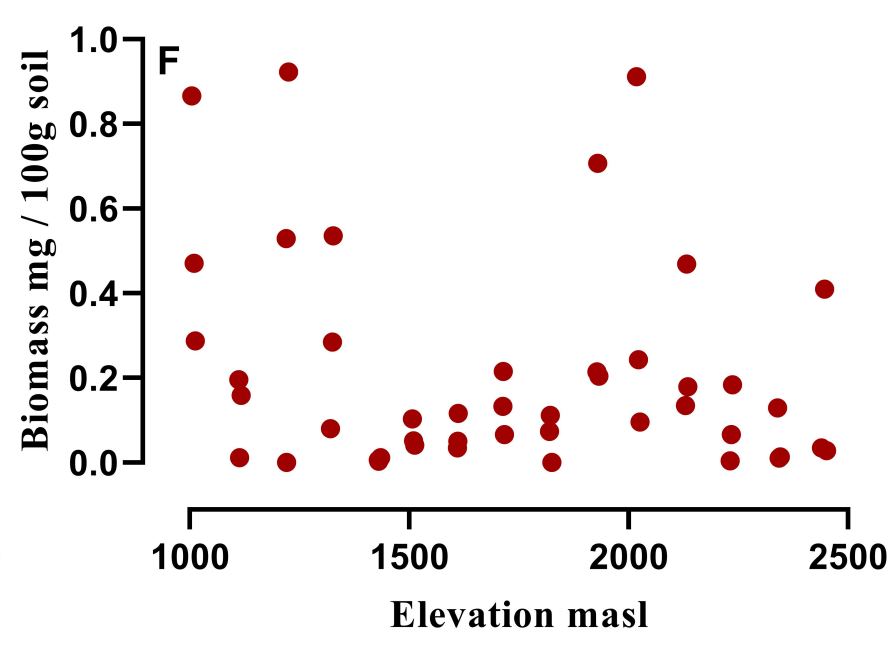



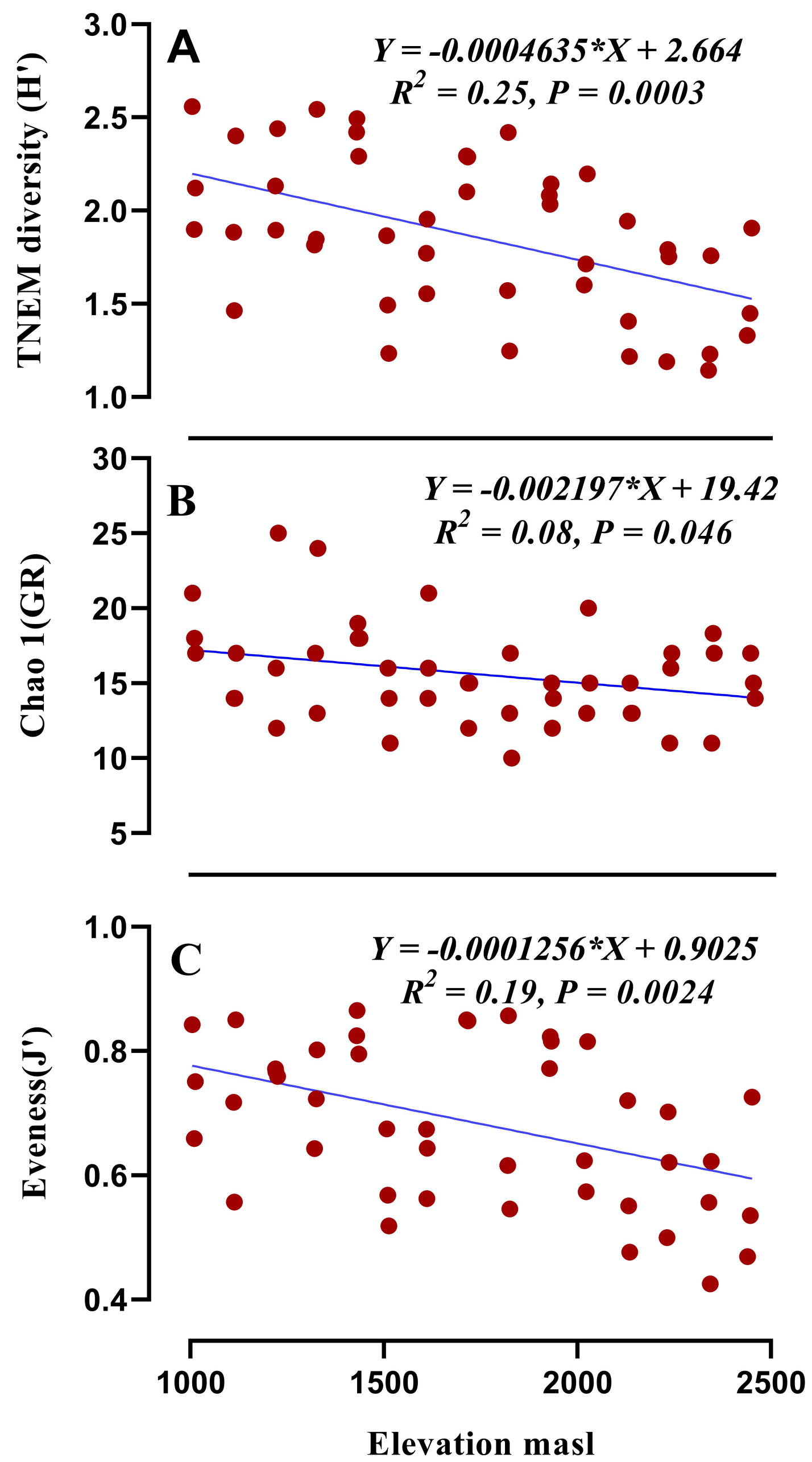

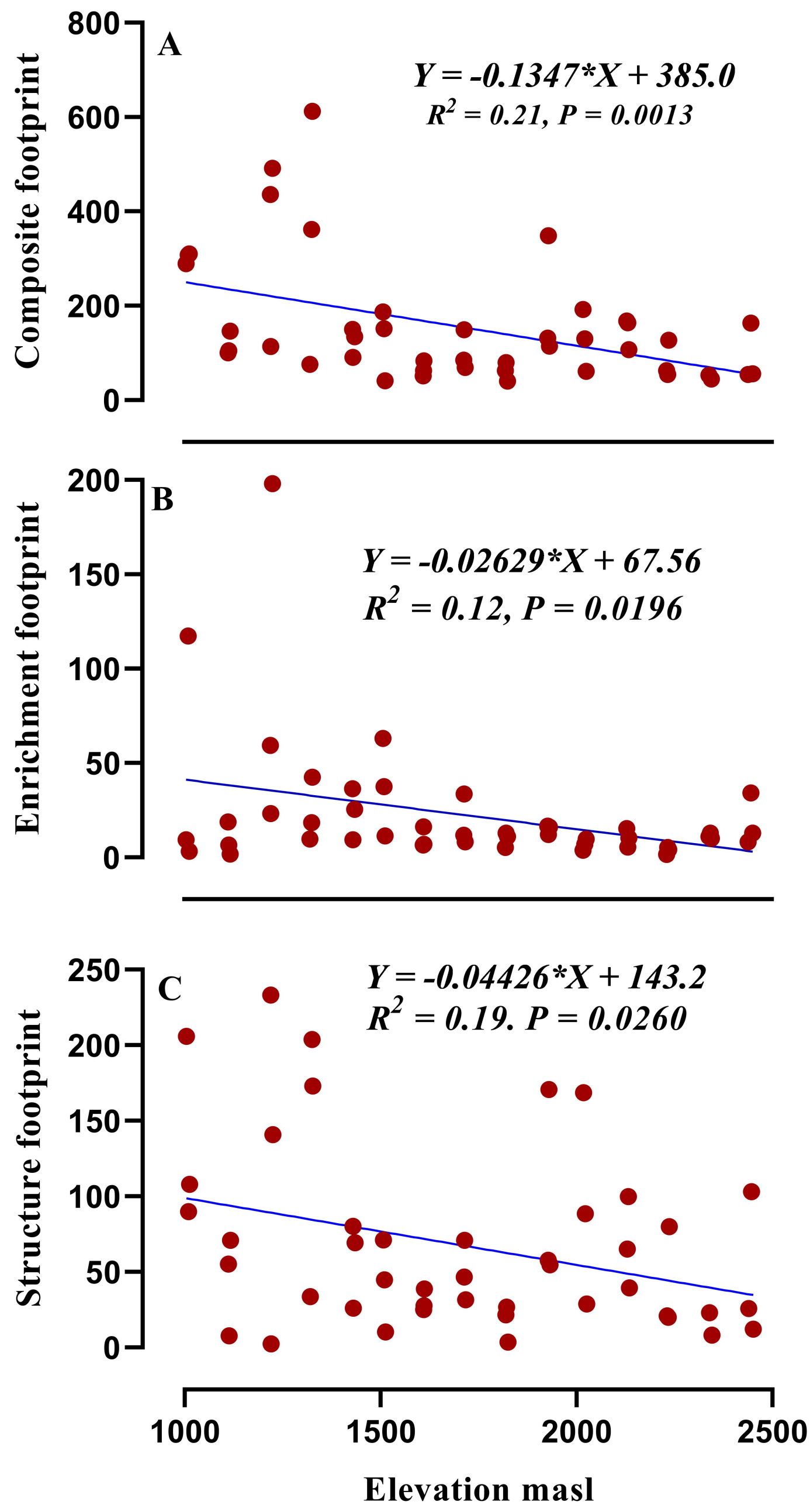

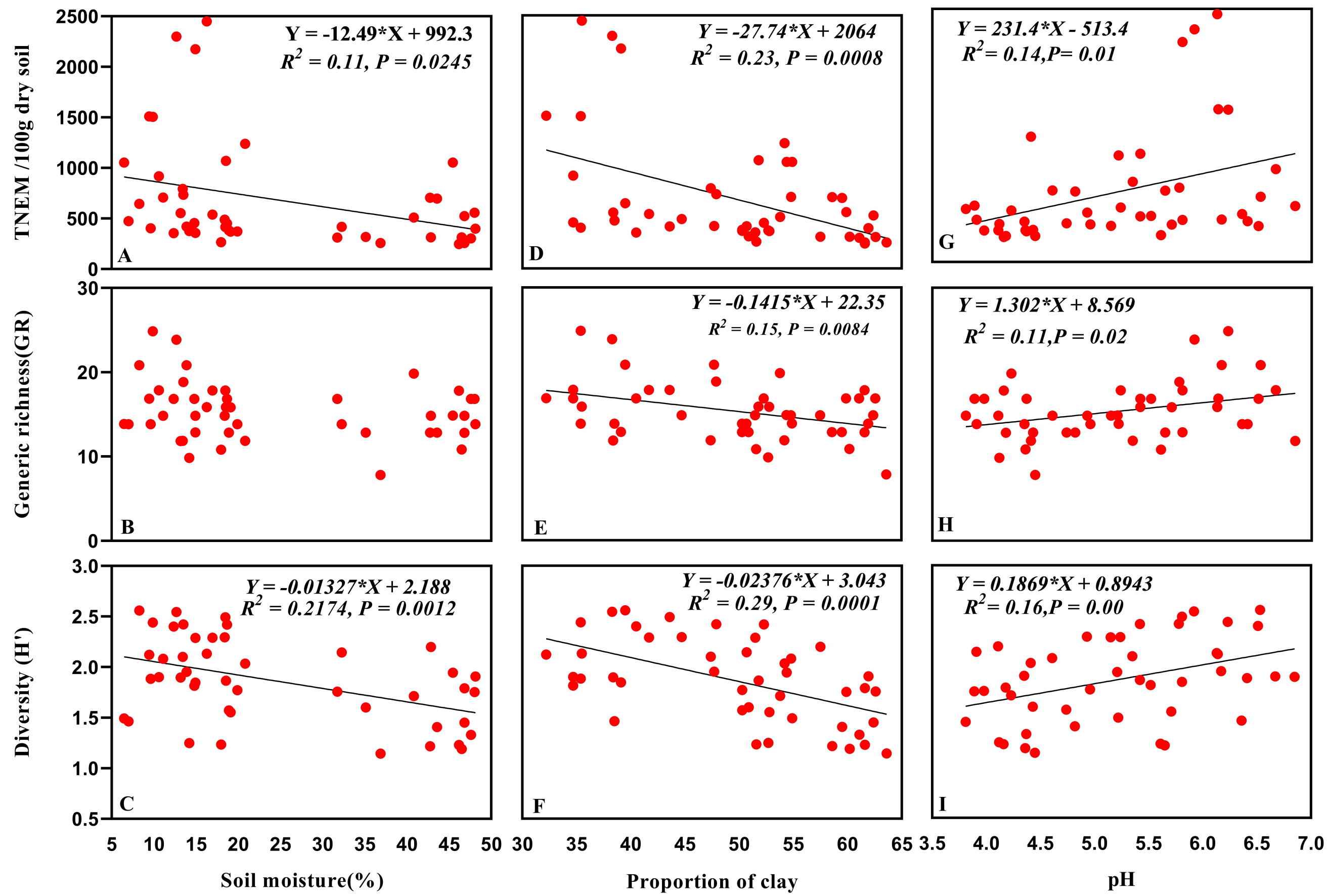
Figures
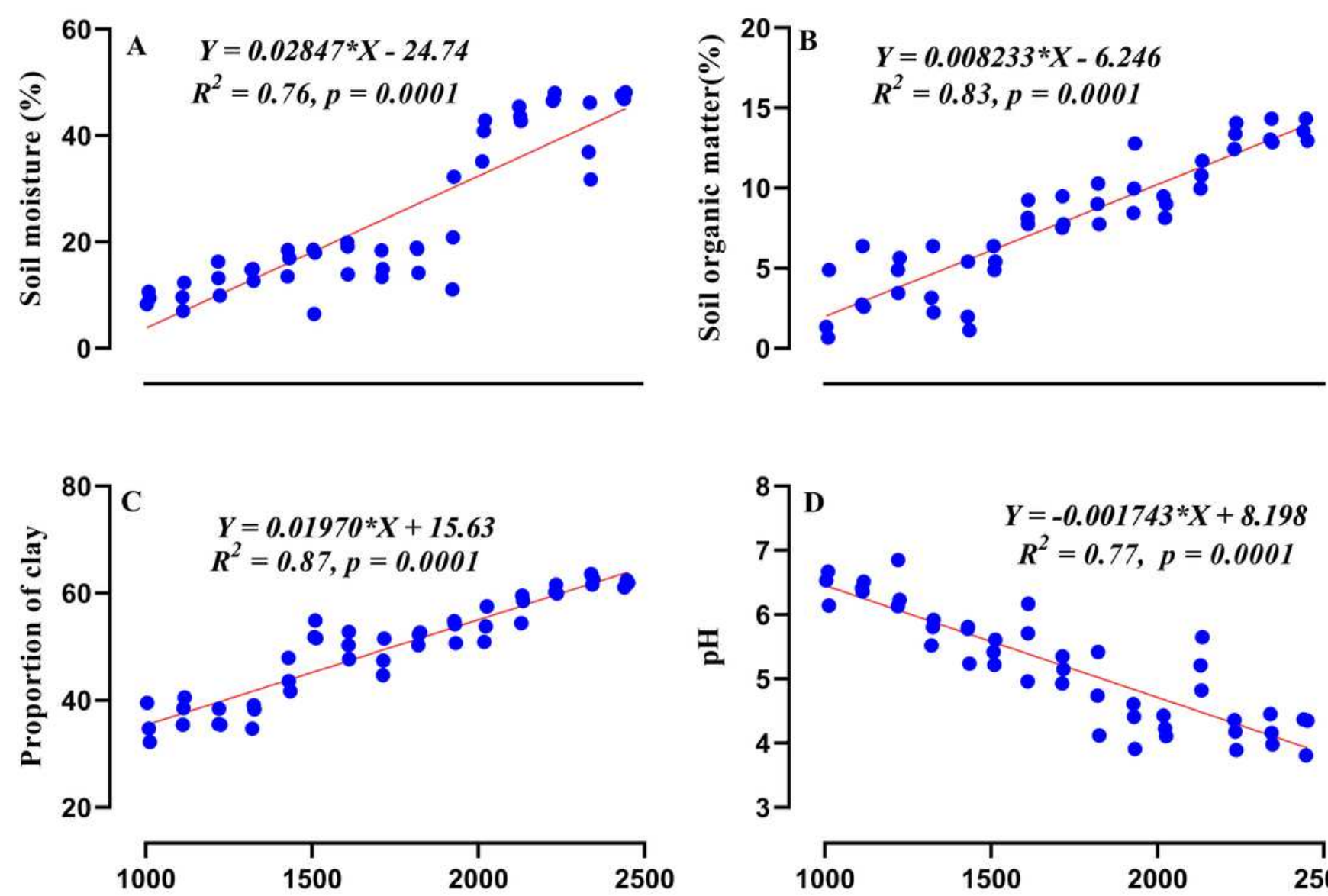

Elevation masl

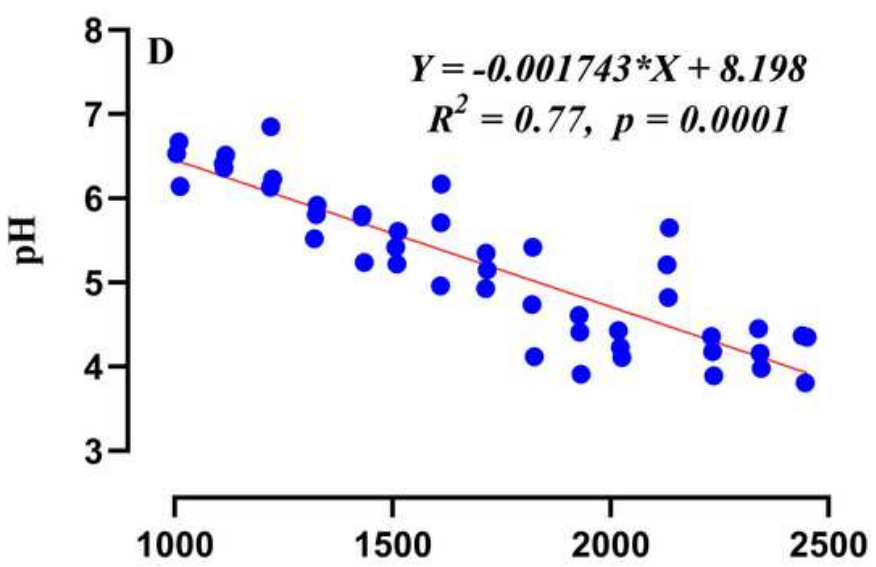

Elevation masl

Figure 1

Effect of elevation on soil moisture (A), soil organic matter (B), proportion of clay (C) and pH (D). Equation for $Y$, R2 (coefficient of determination), $p$ value of linear regression and line of linear regression are shown. 

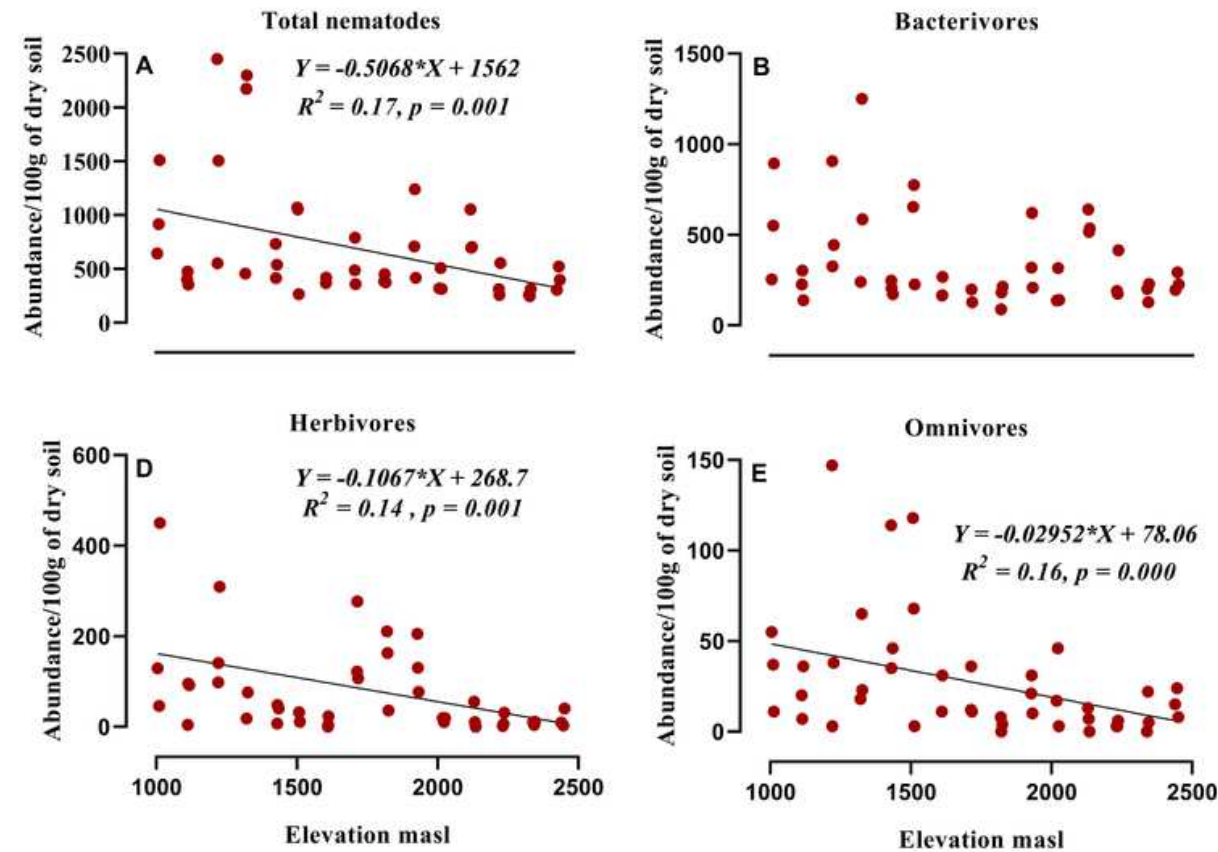
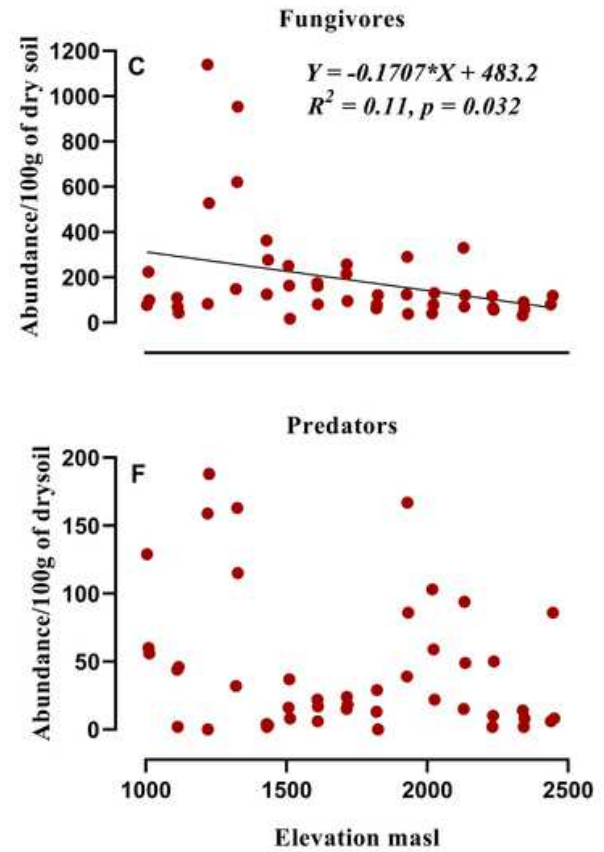

Figure 2

Relationship between elevation and total abundance of nematodes (A), trophic groups: Bacterivores (B), Fungivores (C), Herbivores (D), Omnivore (E), Predators (F). Equation for Y, R2 (coefficient of determination), $p$ (significance) of linear regression and regression line are displayed only for significant relationships.

Total nematodes

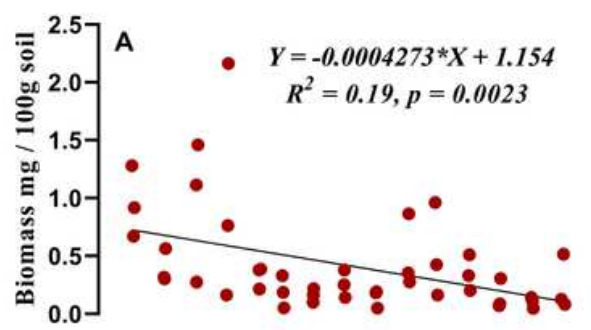

Herbivores

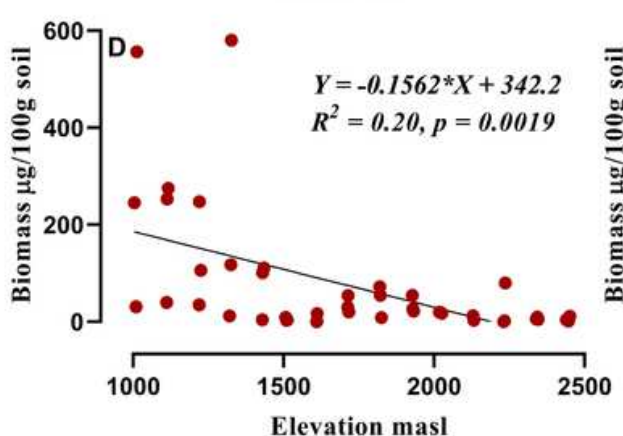

Elevation masl
Bacterivores

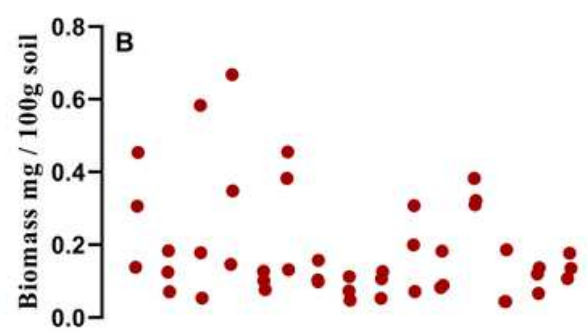

Omnivores

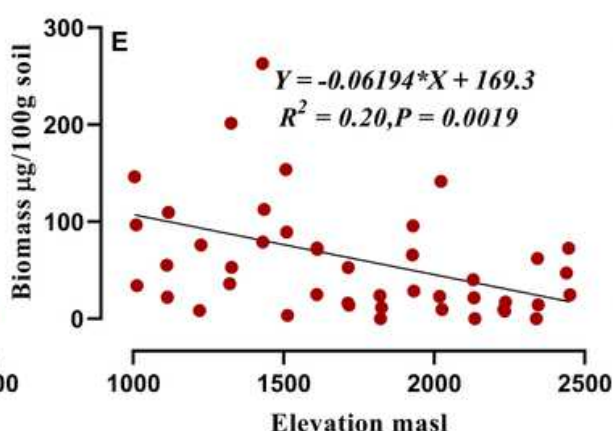

Elevation masl
Fungivores

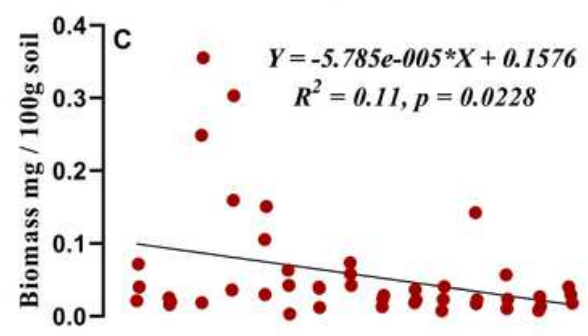

Predator

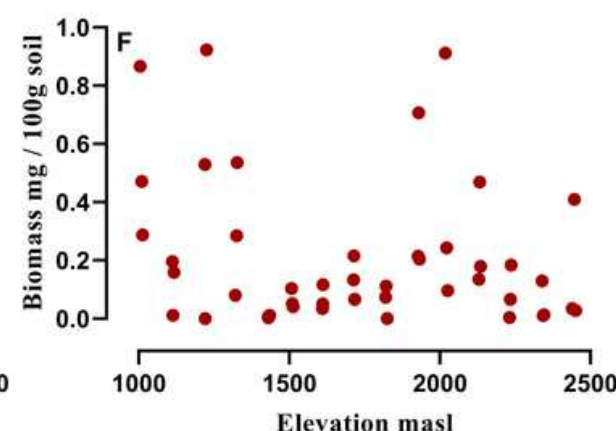


Figure 3

Relationship between elevation and total biomass of nematodes $(A)$, biomass of trophic groups: Bacterivores (B), Fungivores (C), Herbivores (D), Omnivores (E), Predators (F). Equation for $Y, R 2$ (coefficient of determination), $\mathrm{p}$ (significance) of linear regression and regression line are displayed only for significant relationships.
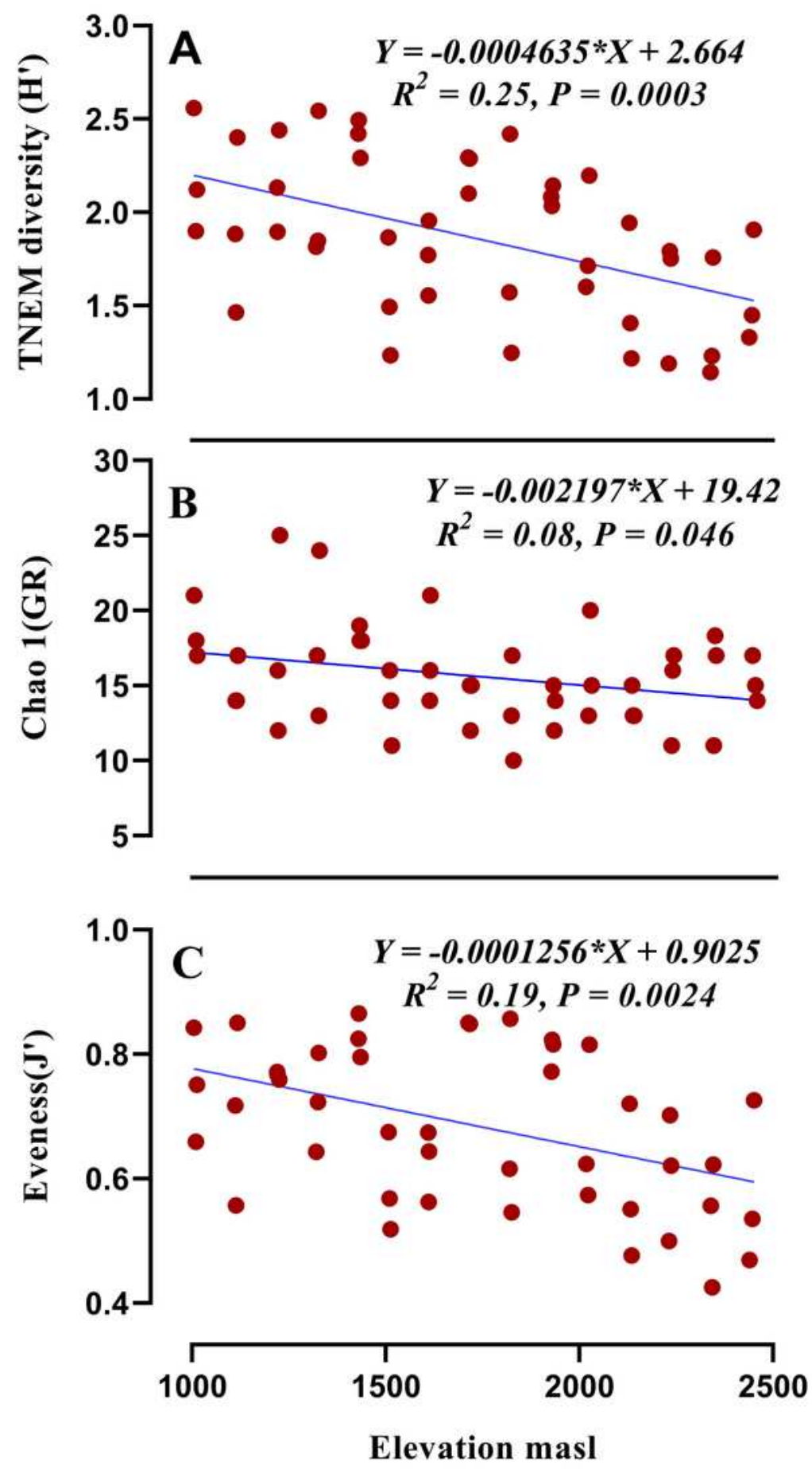

Figure 4 
Relationship between elevation and total nematode diversity (A), generic richness (B) and evenness (C). Equation for $Y, R 2$ (coefficient of determination), $p$ (significance) of linear regression and regression line are displayed only for significant relationships.
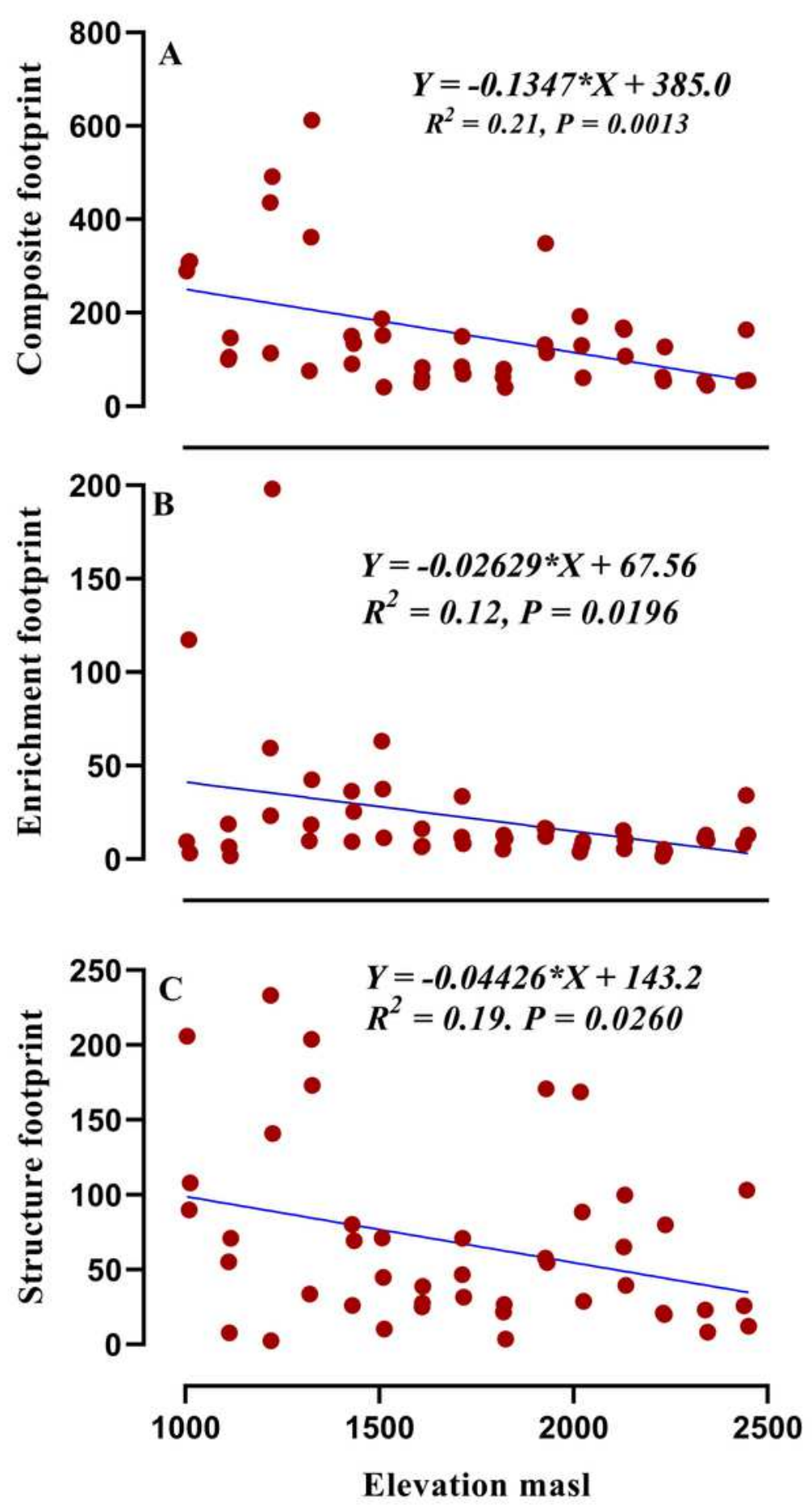

Figure 5

Relationship between elevation and composite metabolic footprint (A), enrichment footprint (B) and structure footprint (C). Equation for Y, R2 (correlation coefficient), p (significance) of linear regression and 
regression line are displayed.
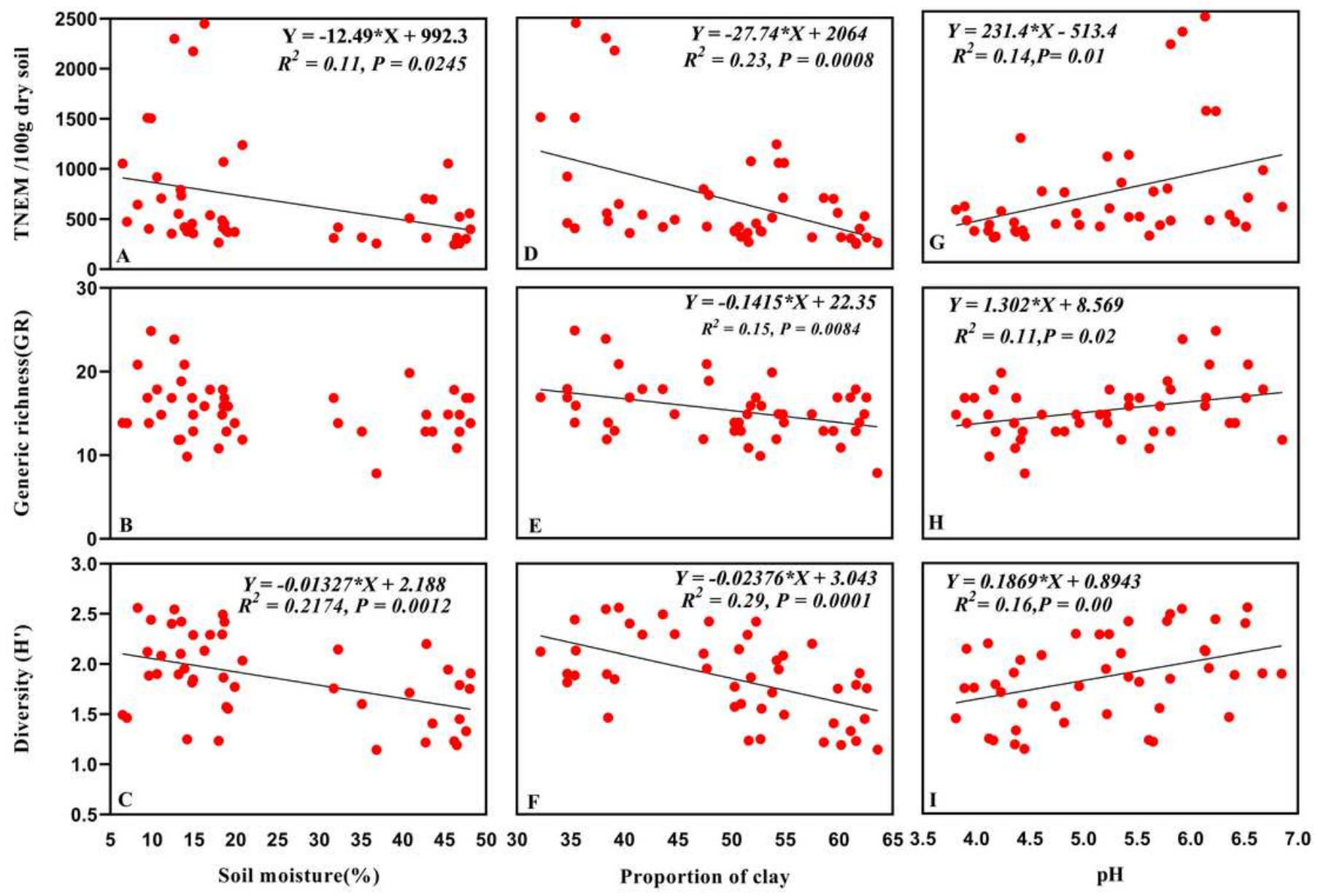

Figure 6

Relationship of soil moisture, and proportion of clay with total nematode abundance, GR and H' (A-I). Equation for $Y$, R2 (coefficient of determination), p (significance) of linear regression and regression line are displayed only for significant relationships.

\section{Supplementary Files}

This is a list of supplementary files associated with this preprint. Click to download.

- FIGS1SUPLEMENTARY.tif 